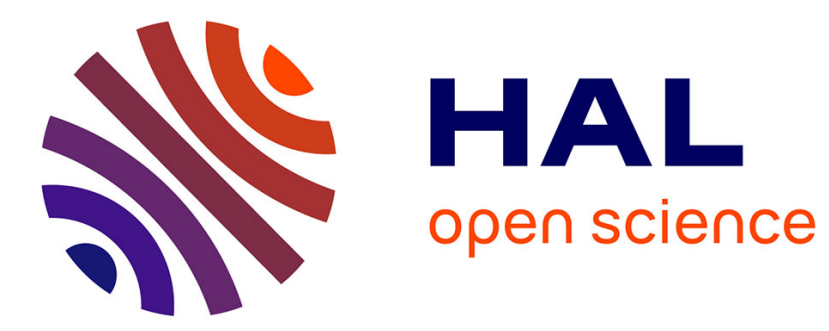

\title{
Sciences, arts et lettres dans les manuels de sociologie
}

Pierre Lassave

\section{To cite this version:}

Pierre Lassave. Sciences, arts et lettres dans les manuels de sociologie. Sociologie de l'art, 2004, Opus 6, pp. 47-68. hal-00273945

\section{HAL Id: hal-00273945 \\ https://hal.science/hal-00273945}

Submitted on 19 Apr 2008

HAL is a multi-disciplinary open access archive for the deposit and dissemination of scientific research documents, whether they are published or not. The documents may come from teaching and research institutions in France or abroad, or from public or private research centers.
L'archive ouverte pluridisciplinaire HAL, est destinée au dépôt et à la diffusion de documents scientifiques de niveau recherche, publiés ou non, émanant des établissements d'enseignement et de recherche français ou étrangers, des laboratoires publics ou privés. 


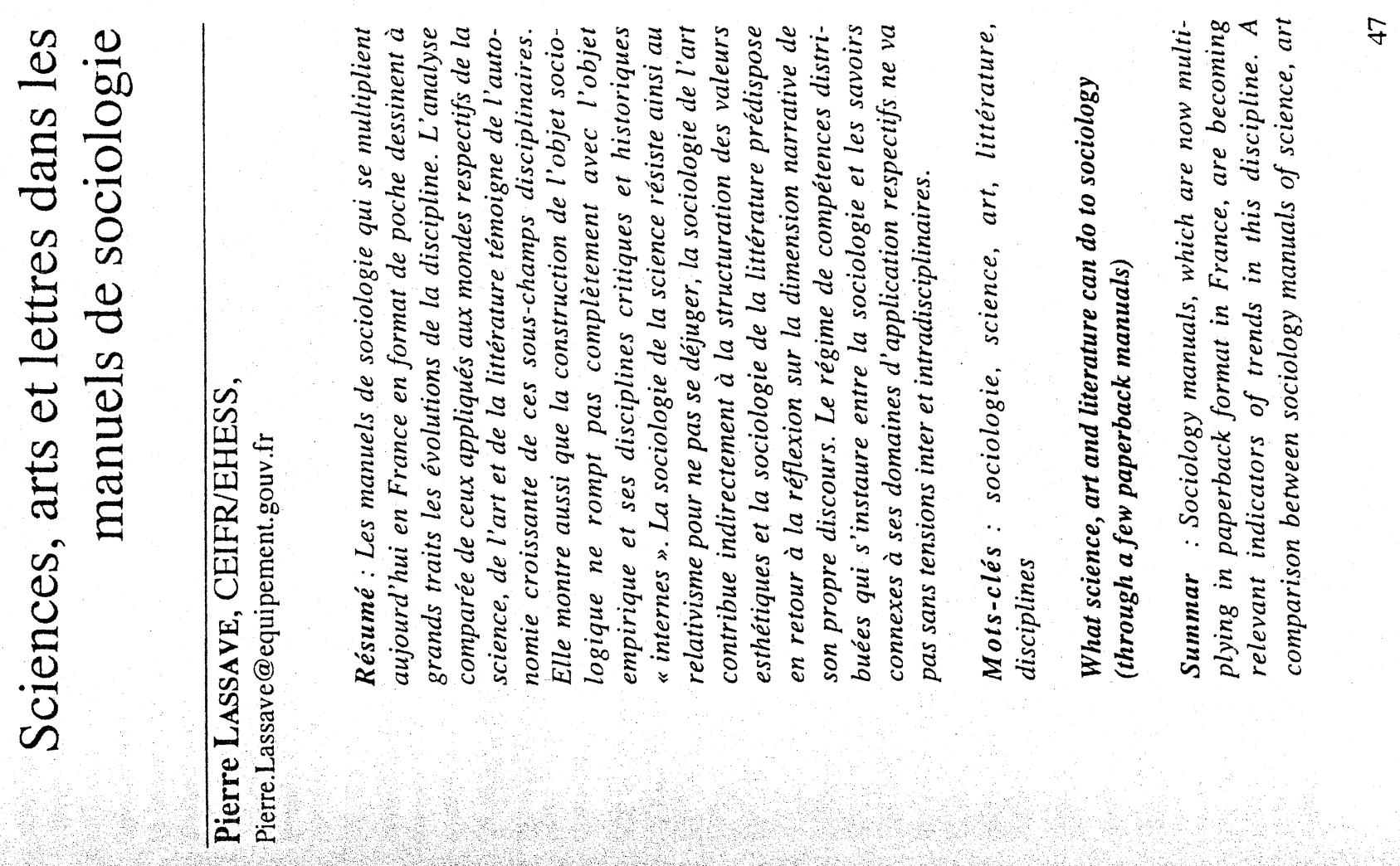




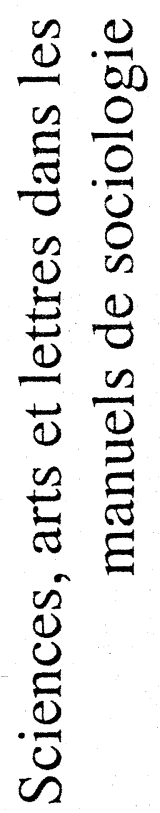

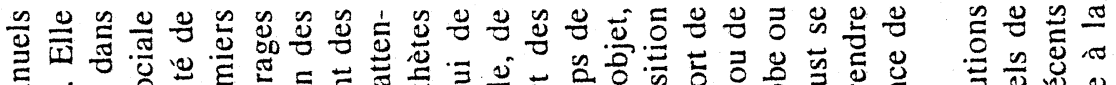

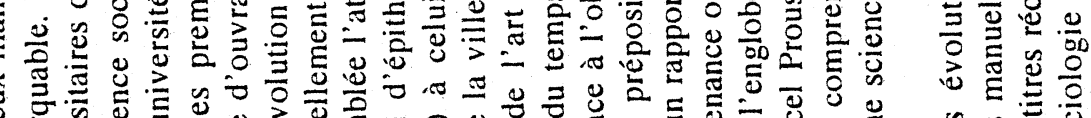

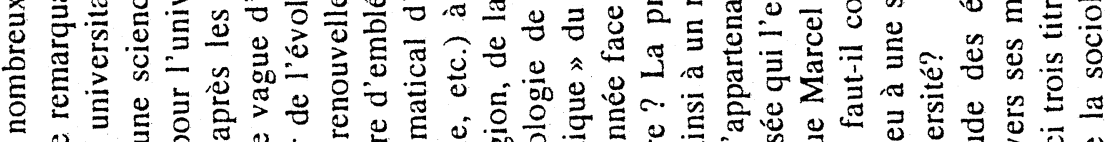

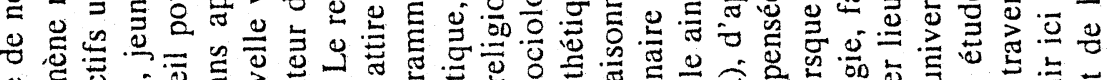

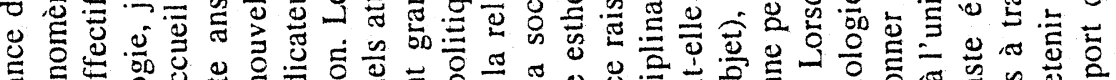

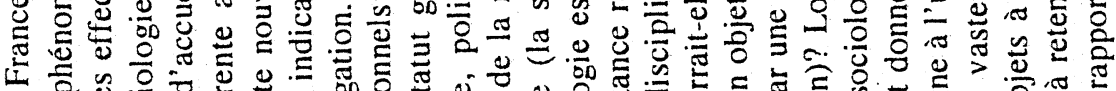
б

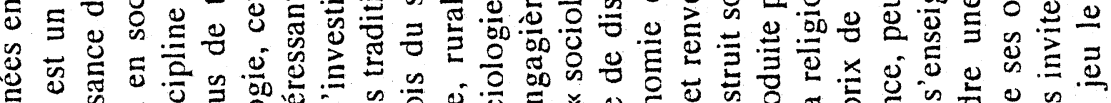

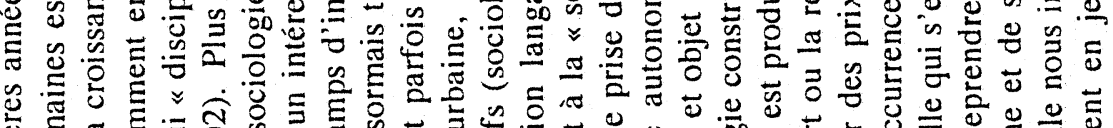

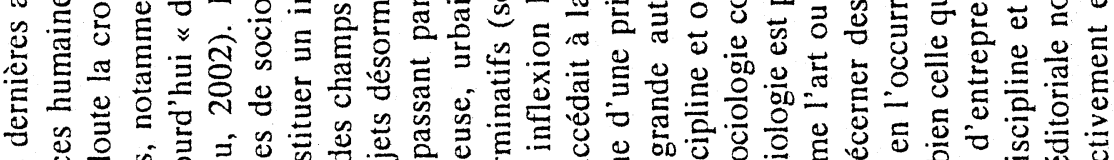

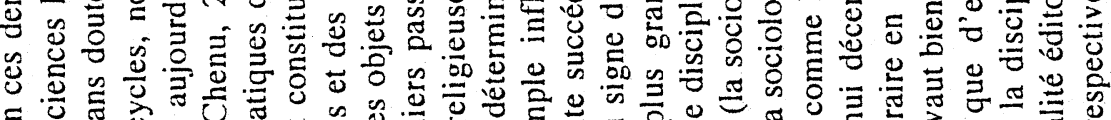

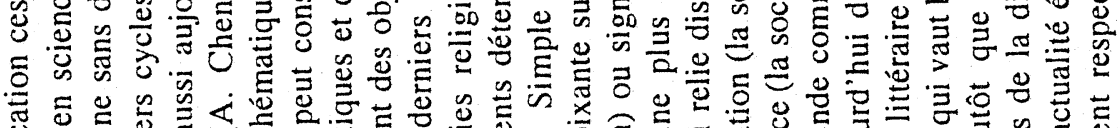

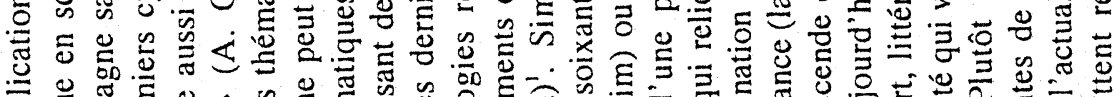

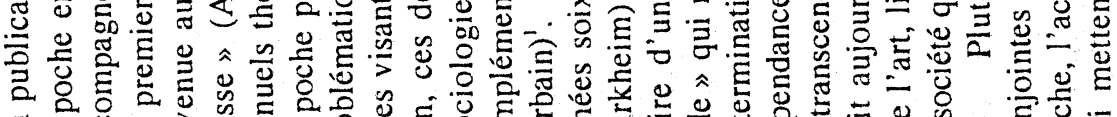

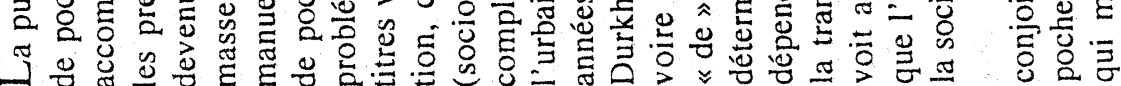

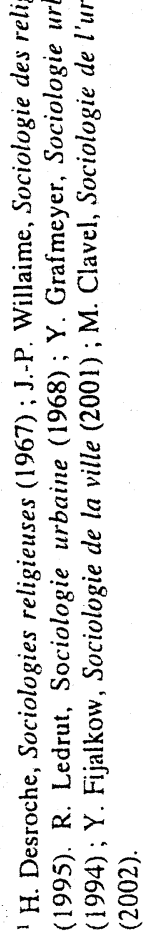




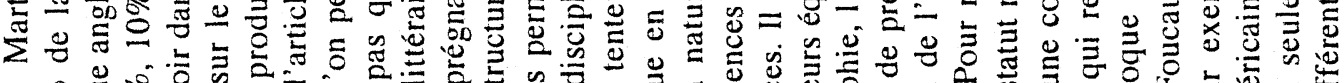

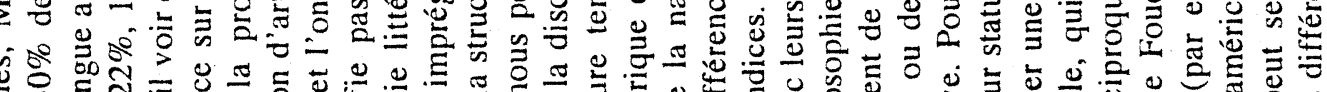

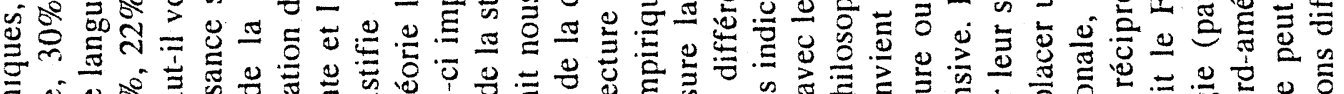

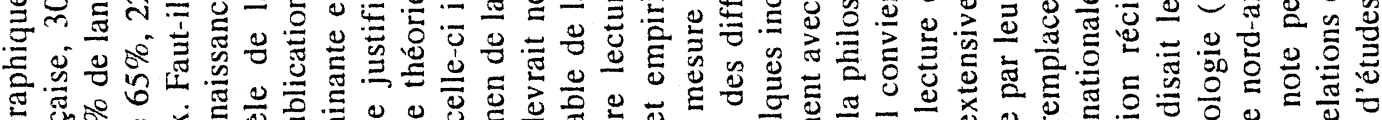

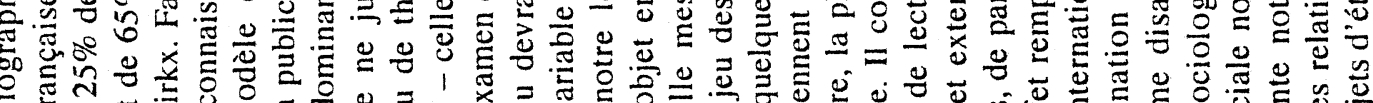

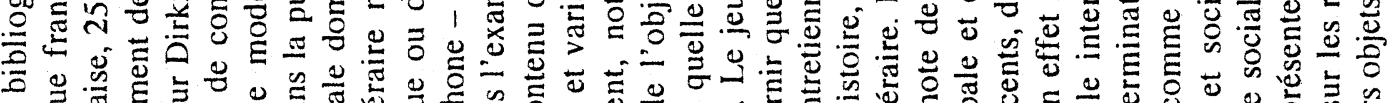

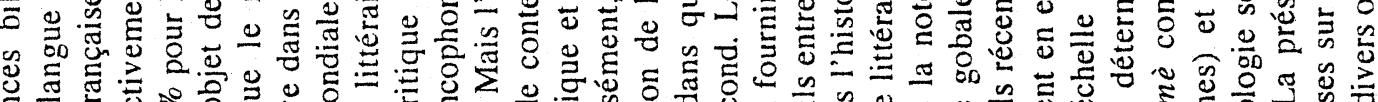

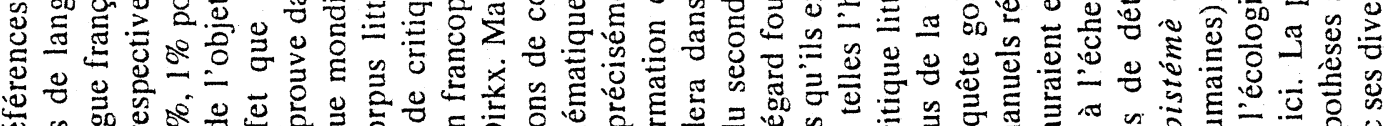

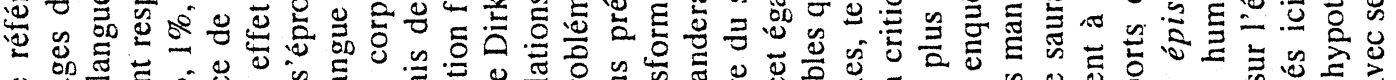

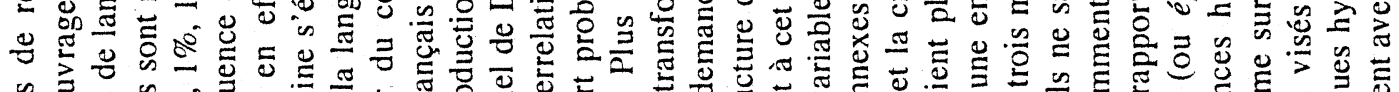

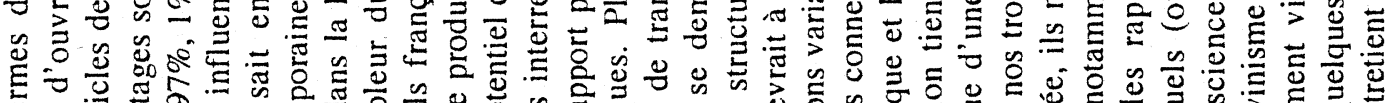

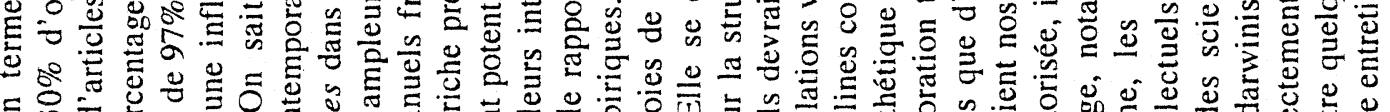

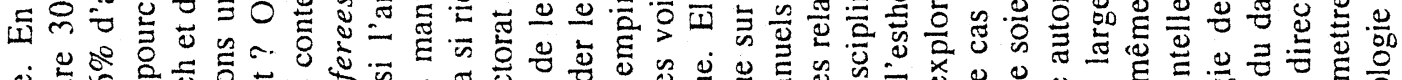

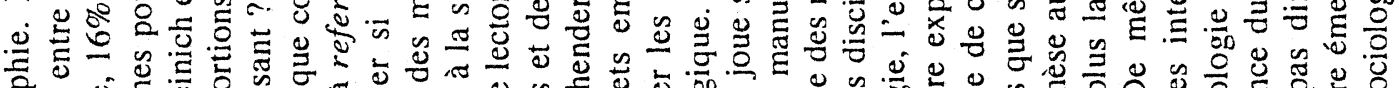

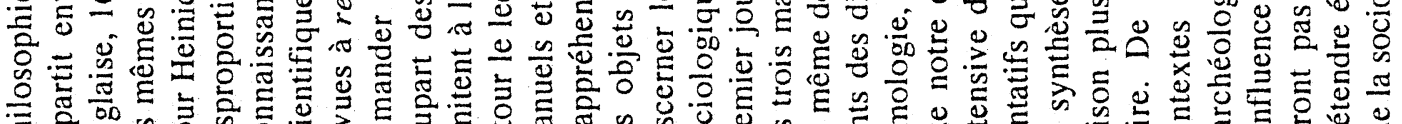

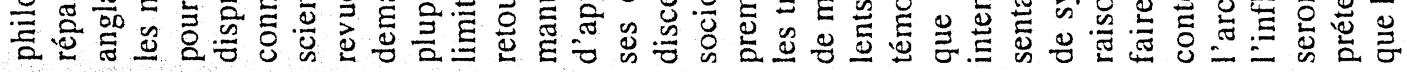

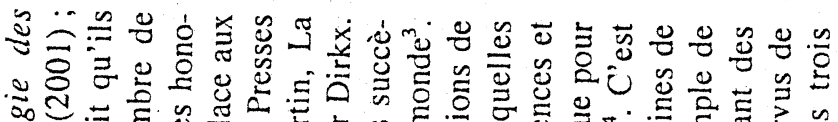

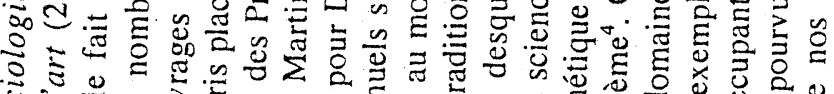

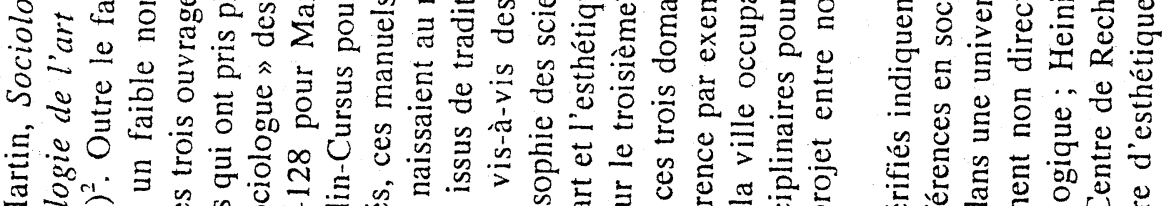

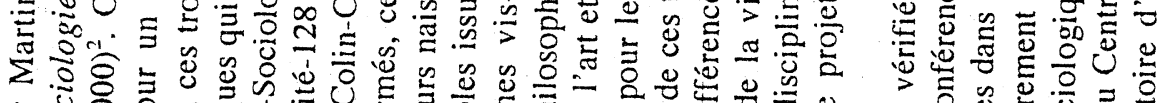

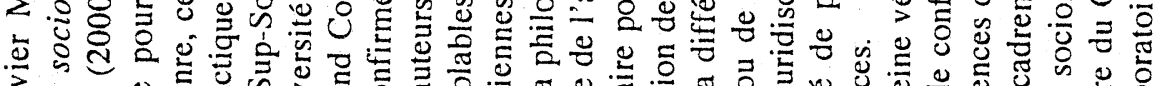

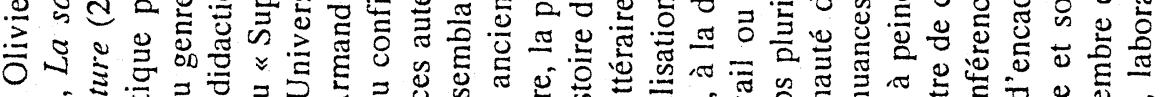

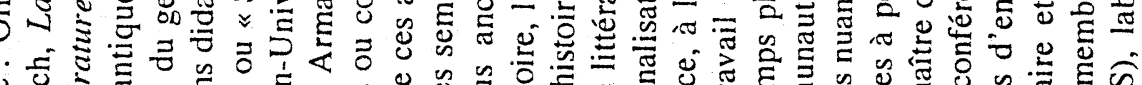

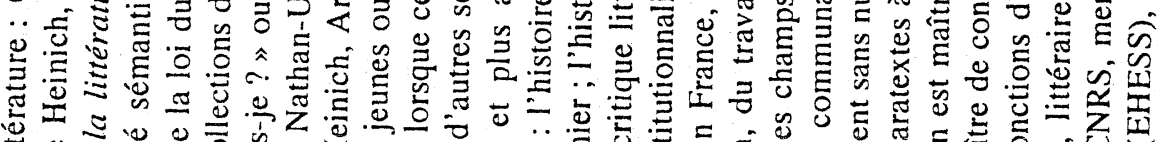

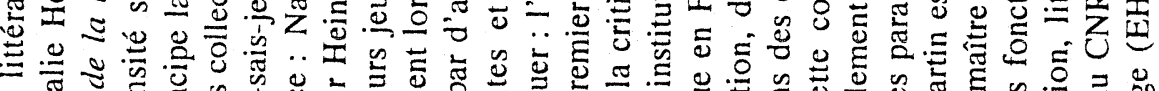

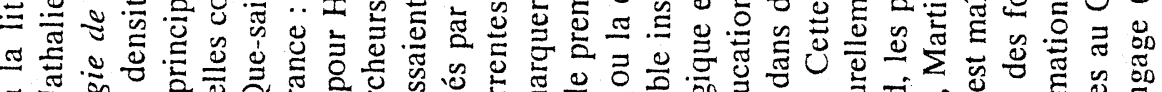

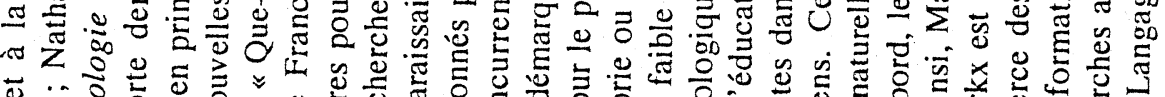

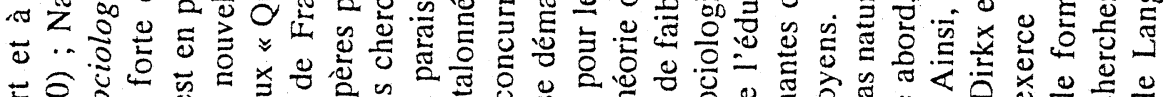

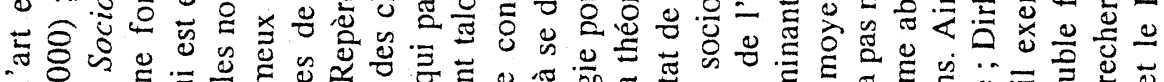

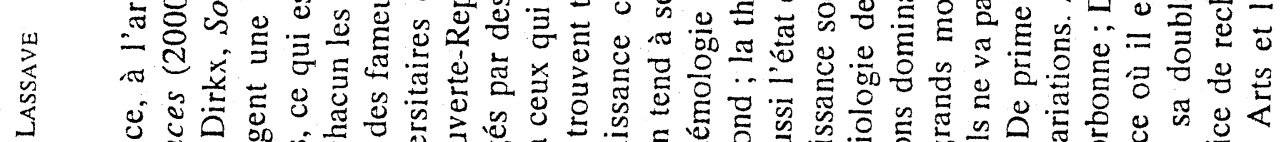

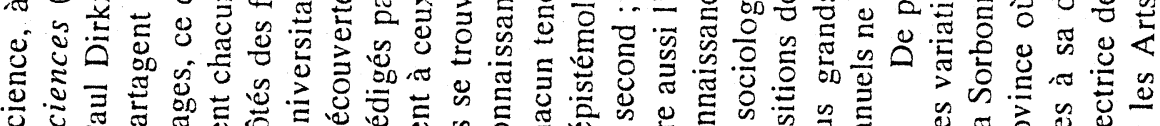

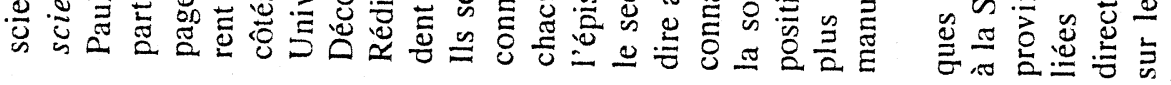

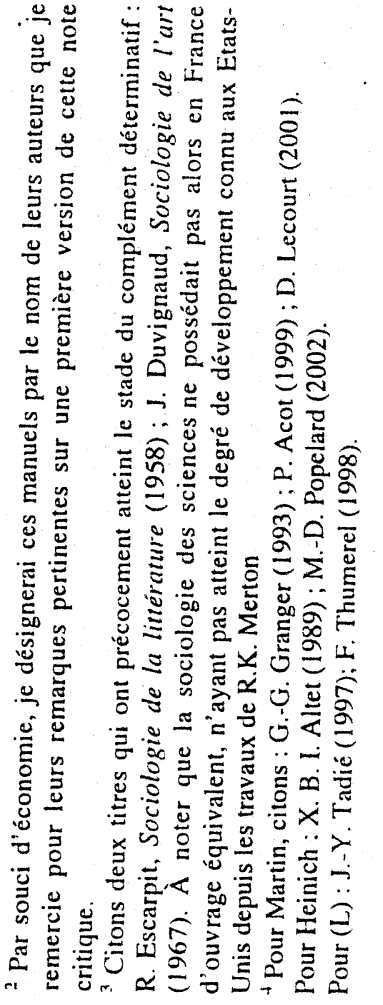

in 


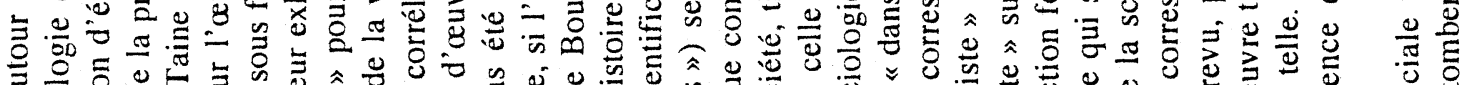

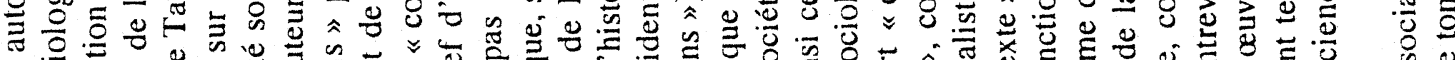

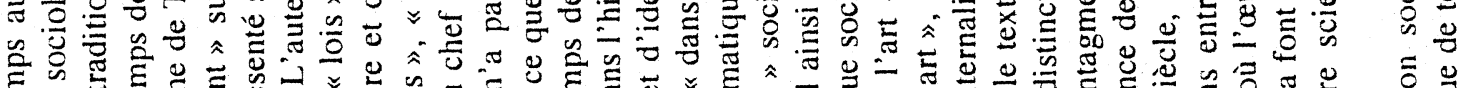

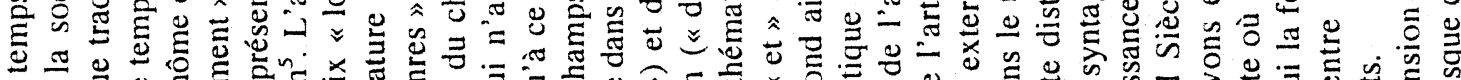

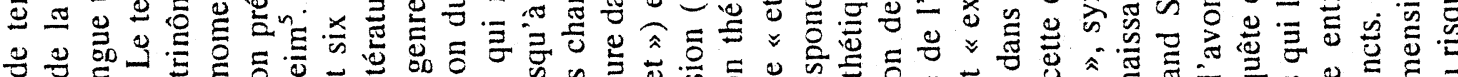

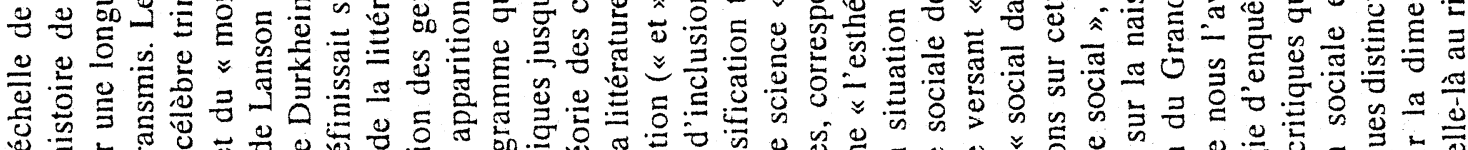
\&.

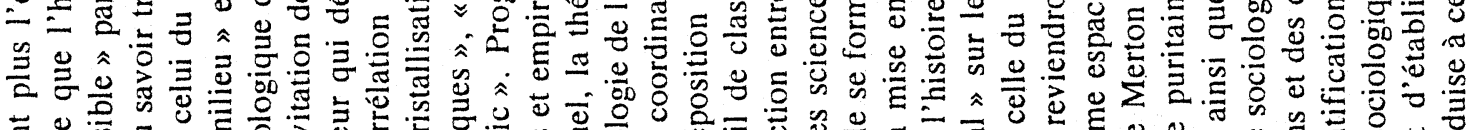

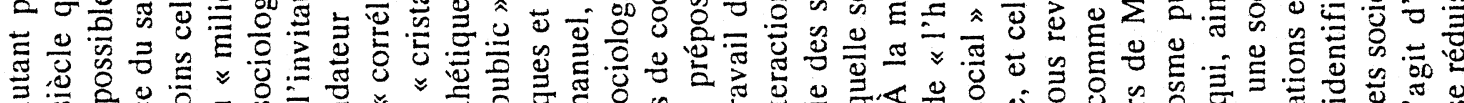

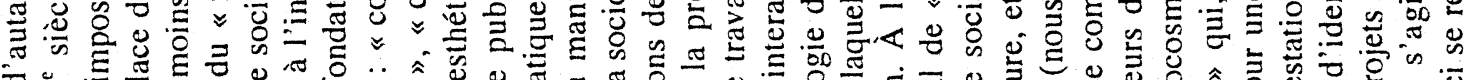

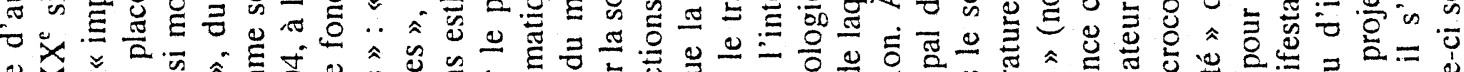

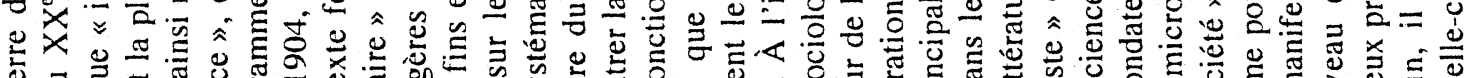

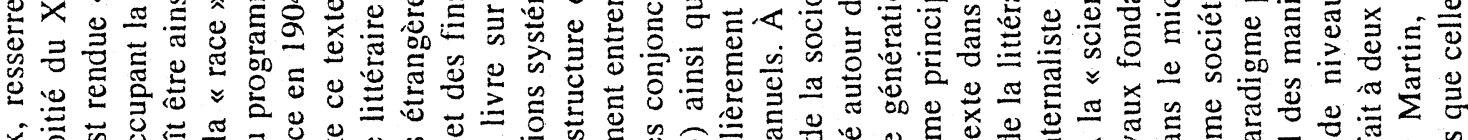

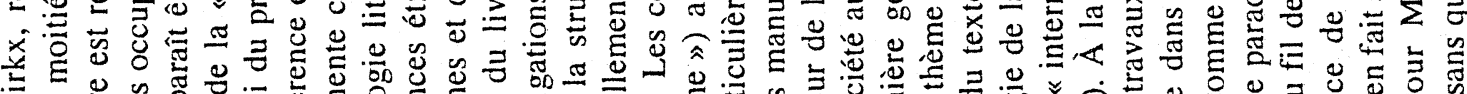

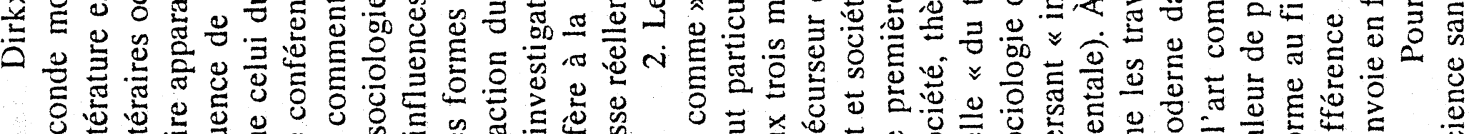

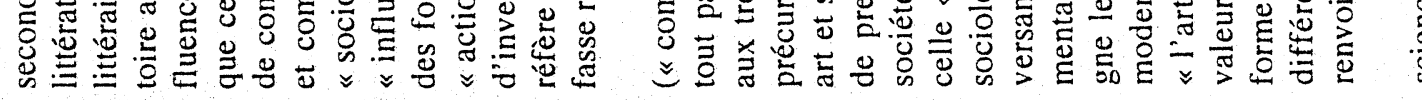

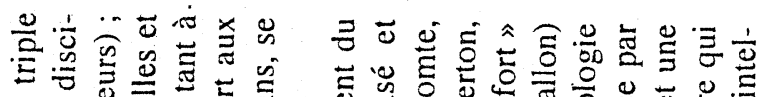

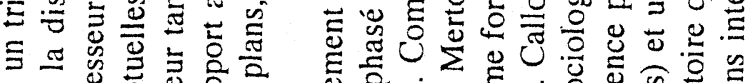

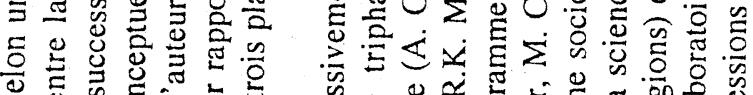
额

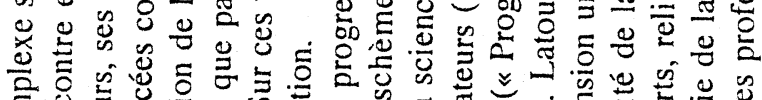

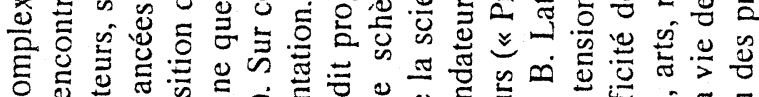

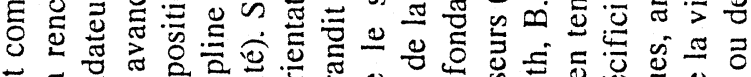

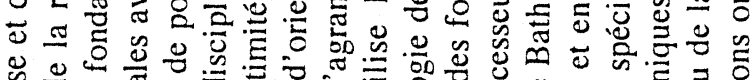

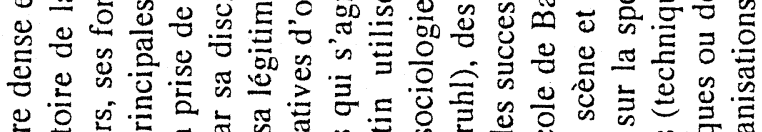

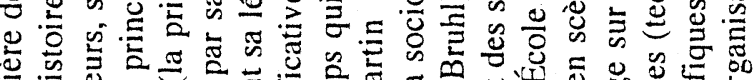

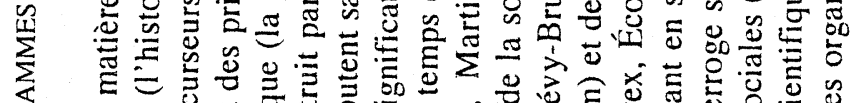

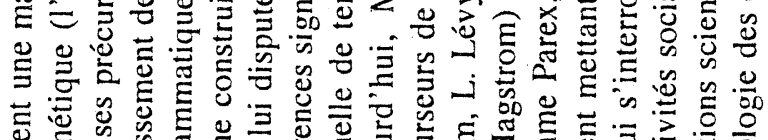

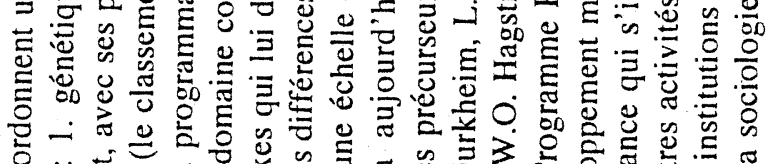

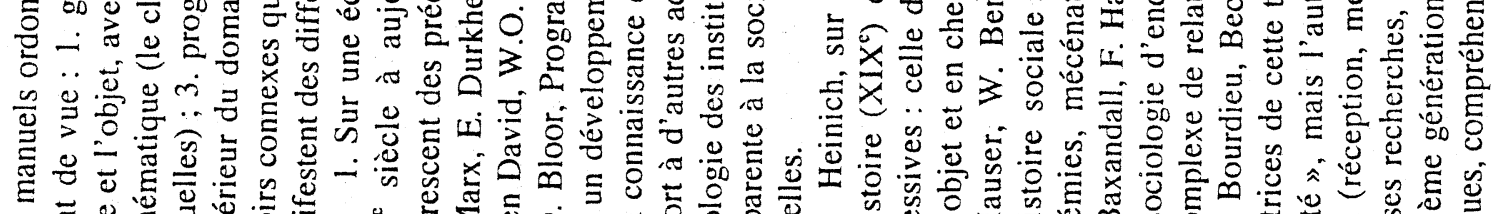

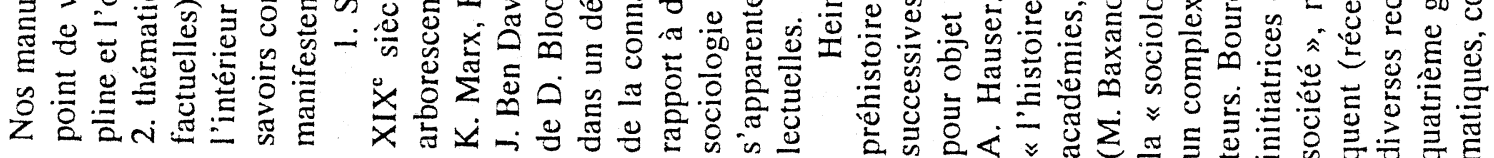

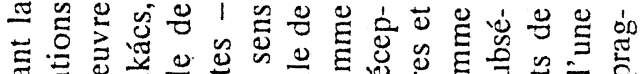

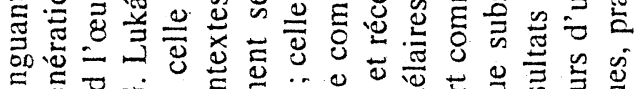

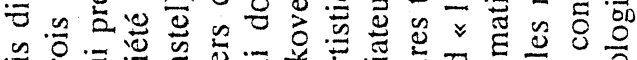

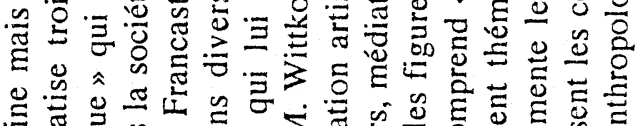

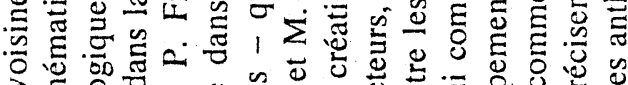

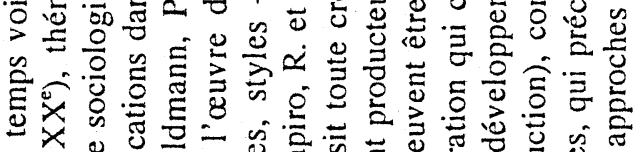

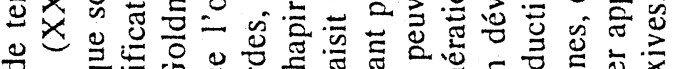

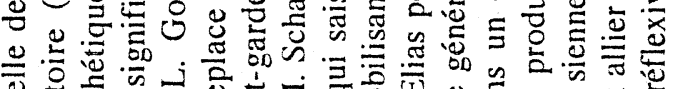

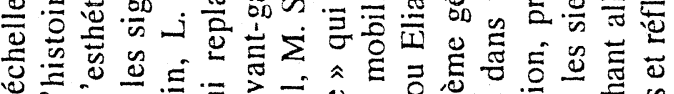

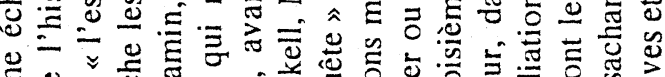

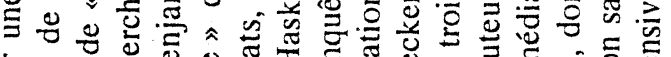

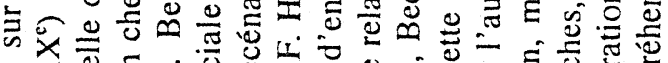

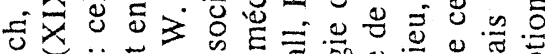

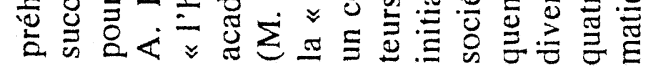

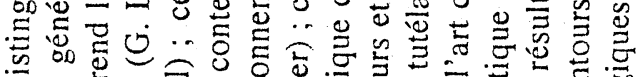




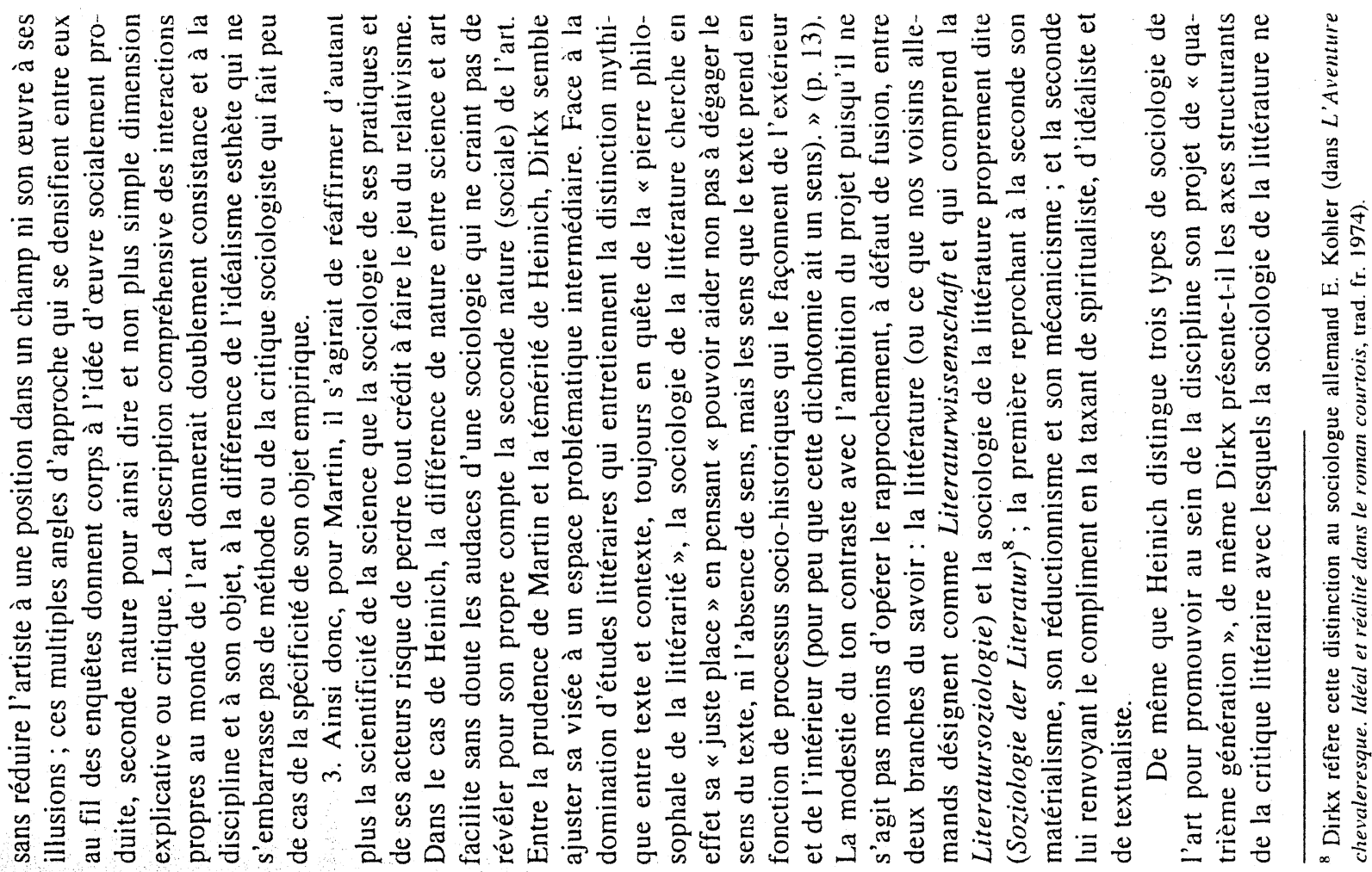

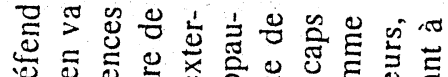

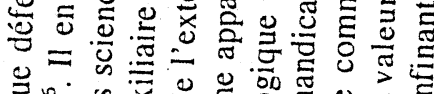

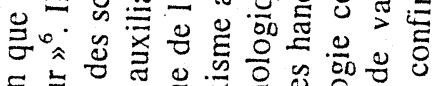

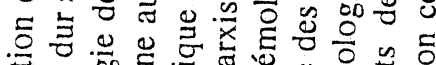

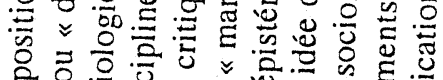

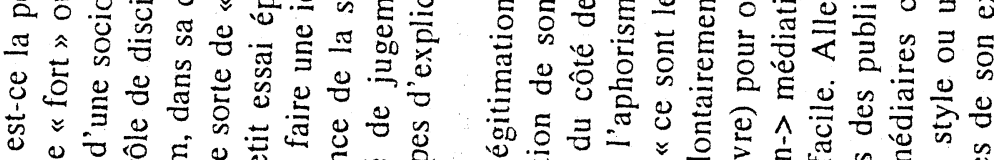

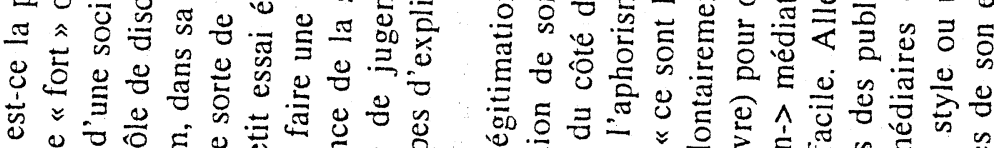

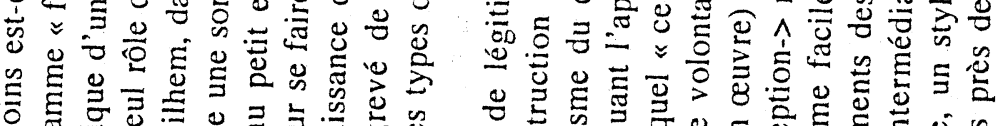

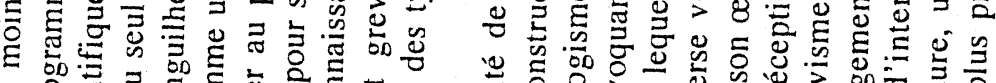

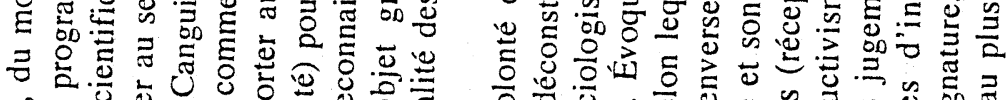

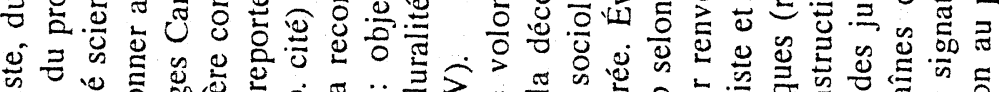

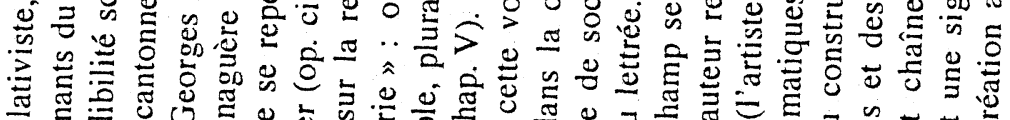

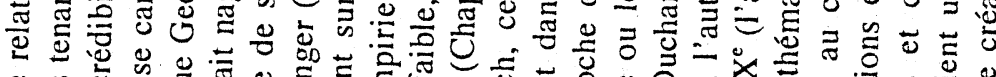

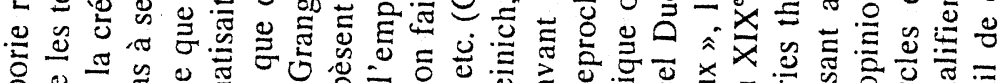

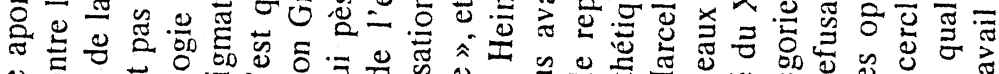

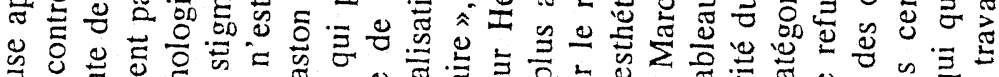

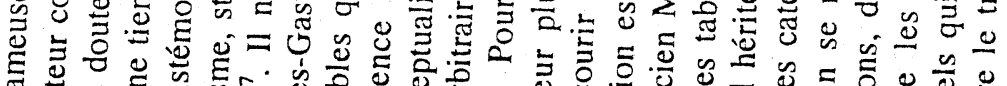

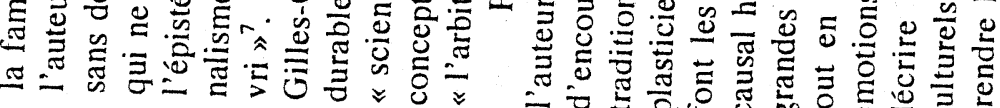

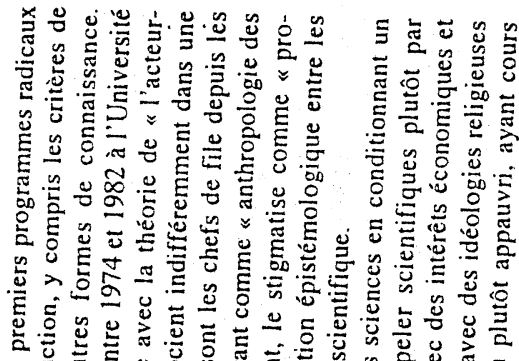

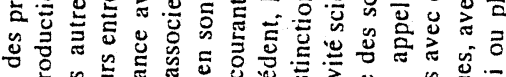

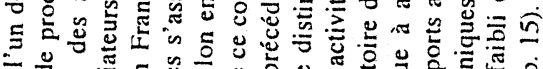

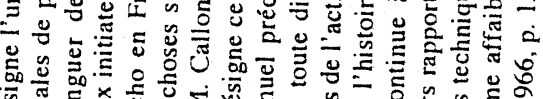

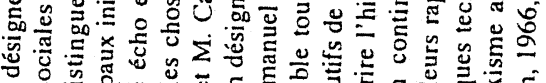

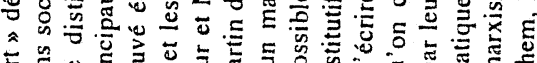

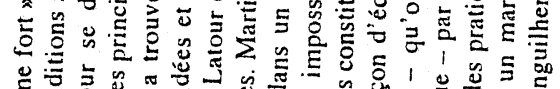

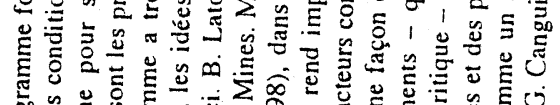

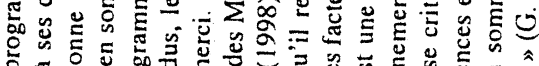

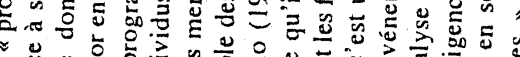

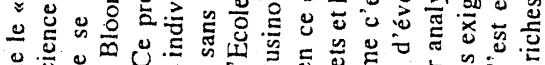

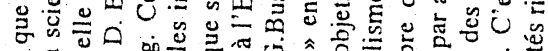

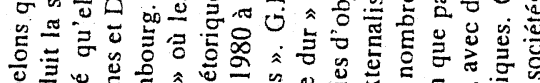

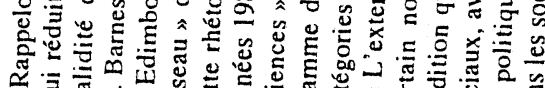




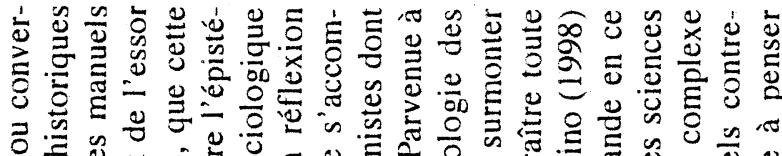

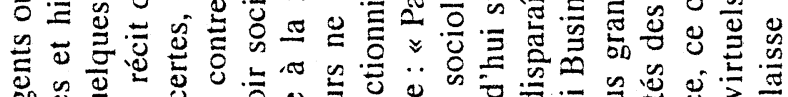

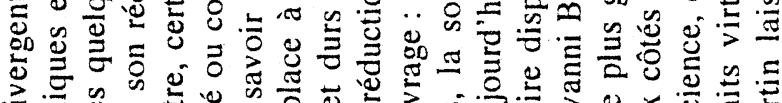

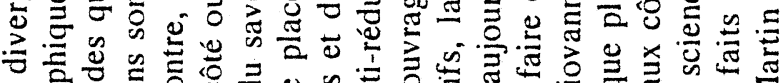

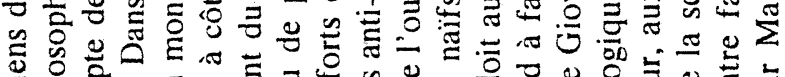

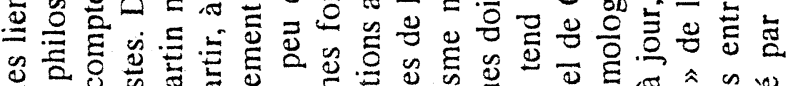

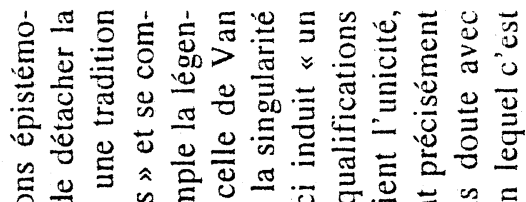

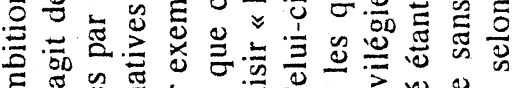

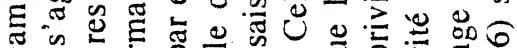

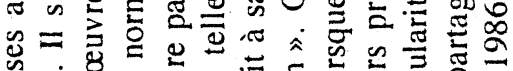

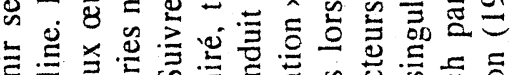

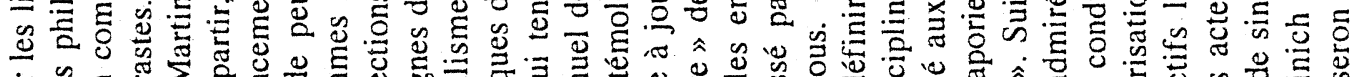

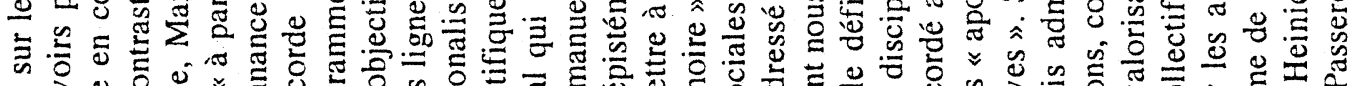

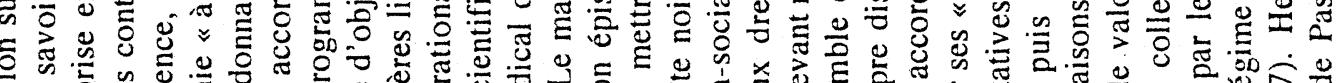

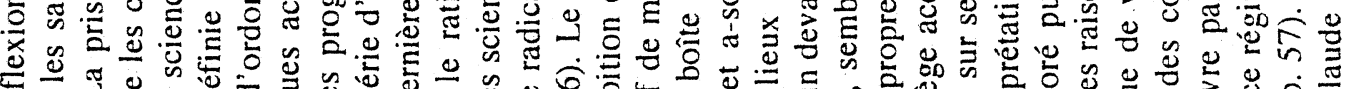

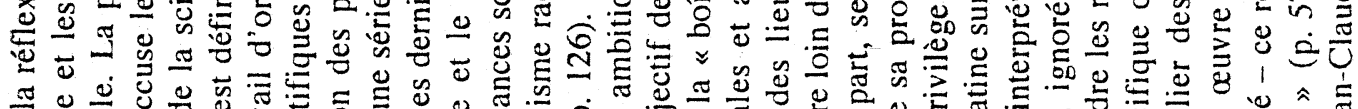

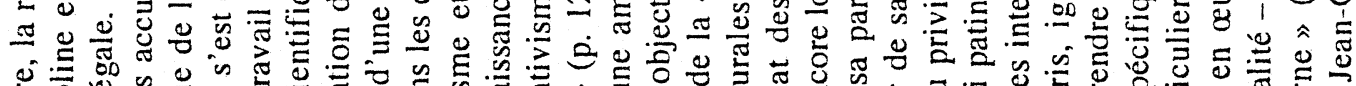

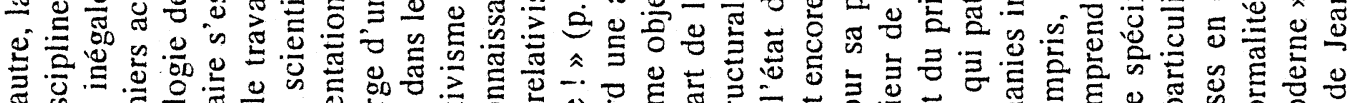

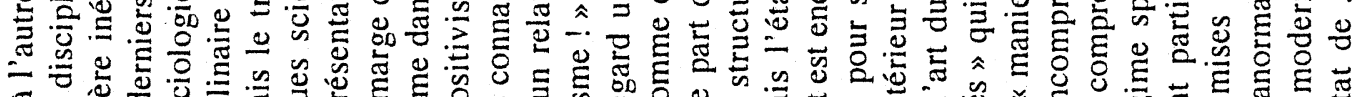

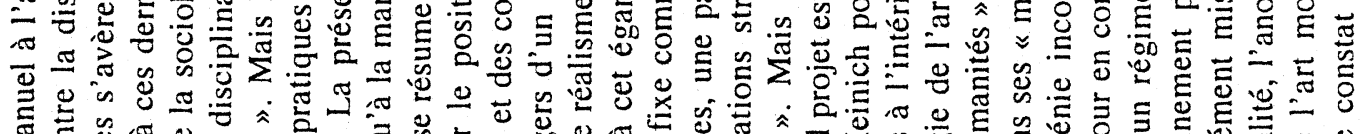

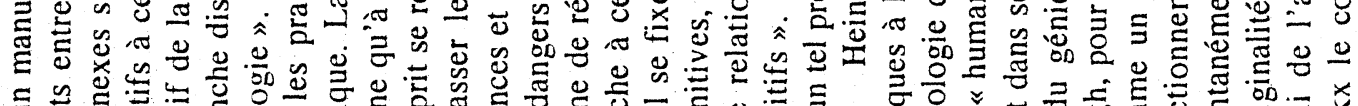

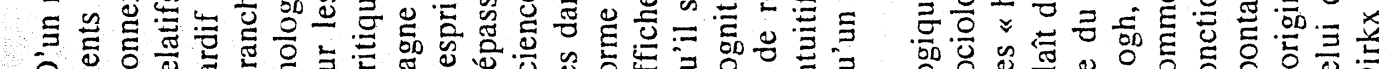

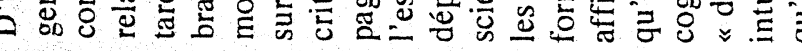

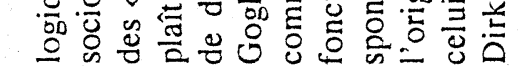

홀

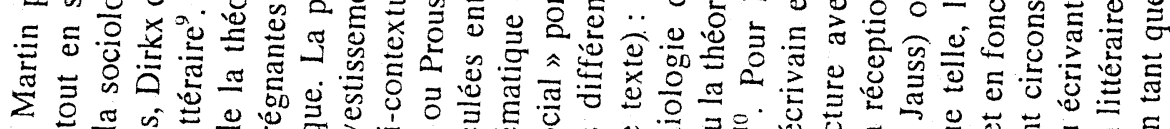
等

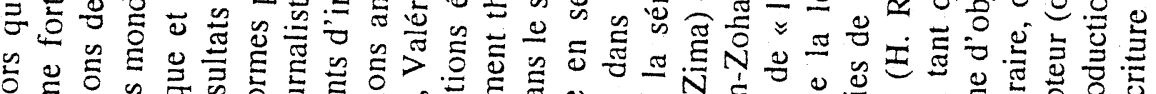

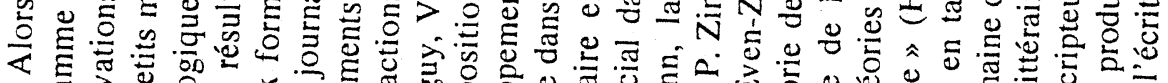
-

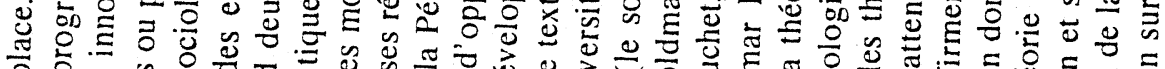

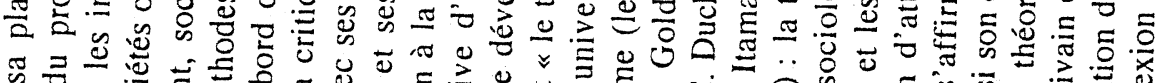

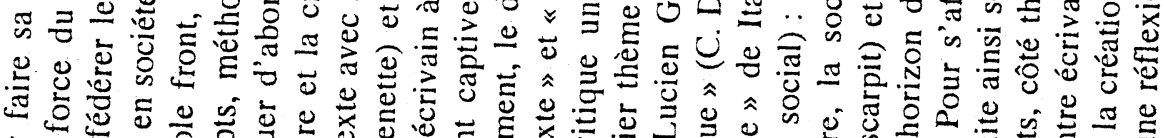

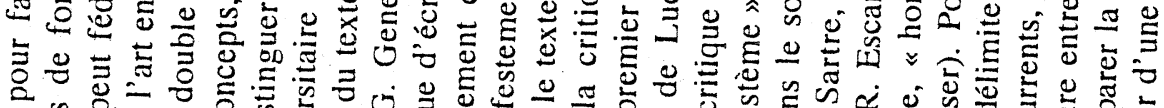
4.

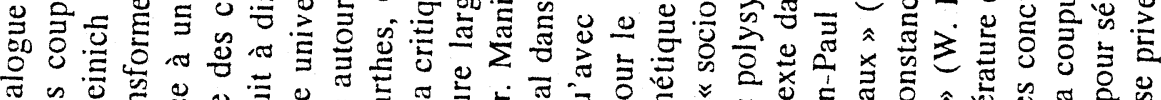

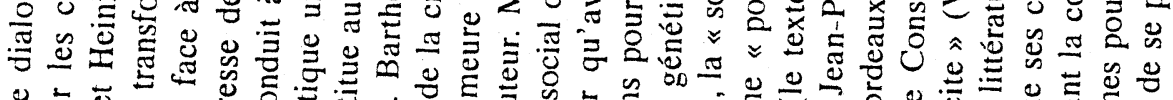

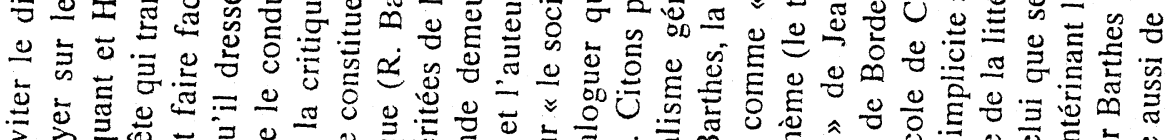

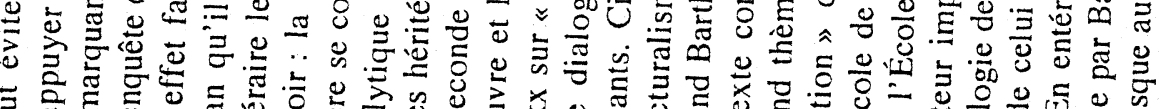

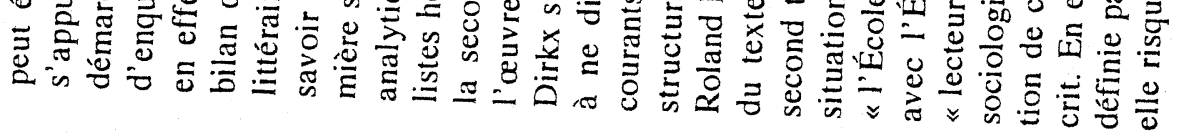

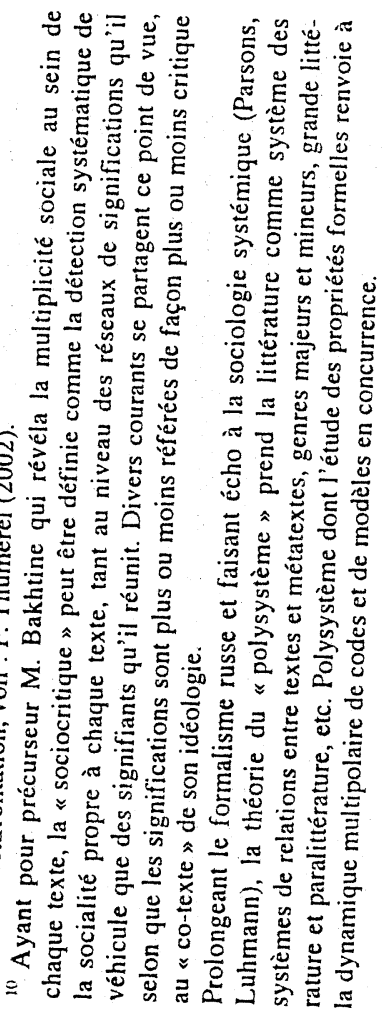




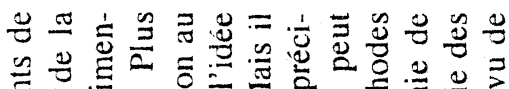

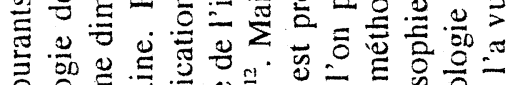

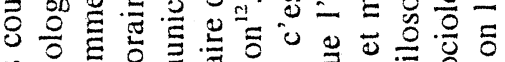

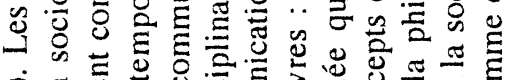

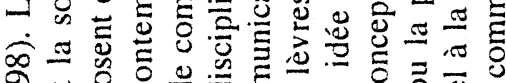

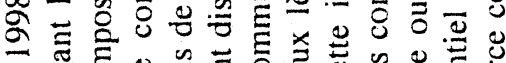

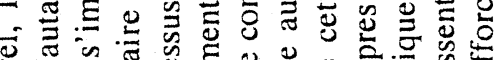

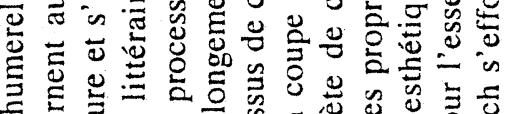

E

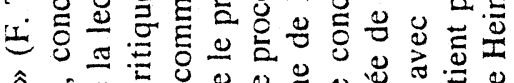

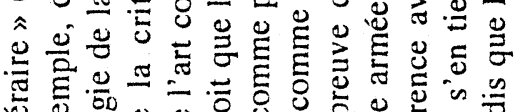

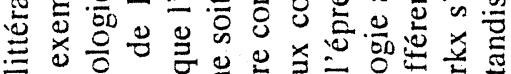

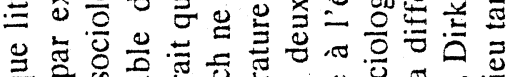

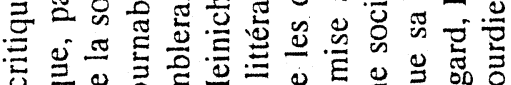

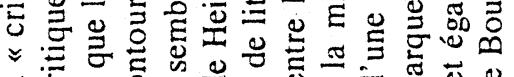

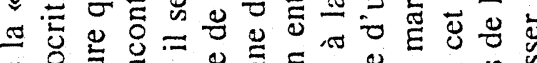

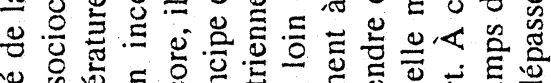

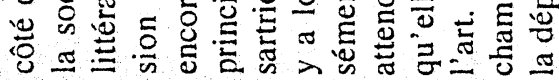

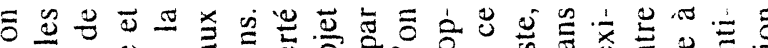

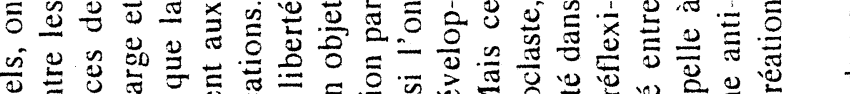

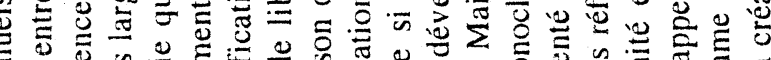

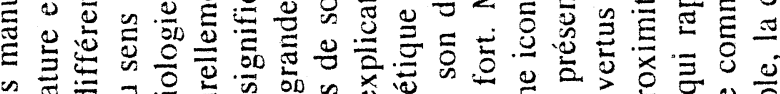

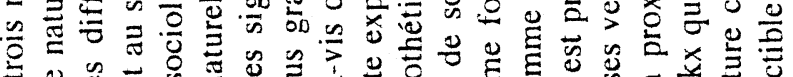

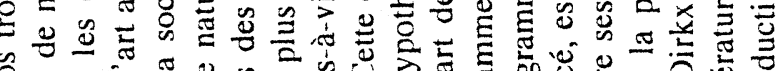

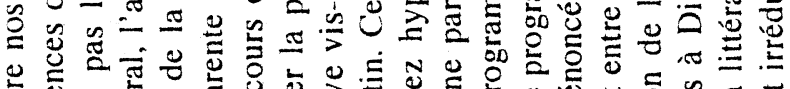

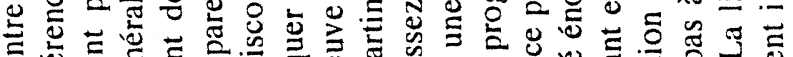

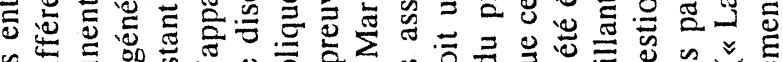

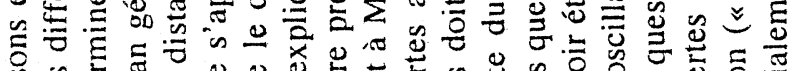

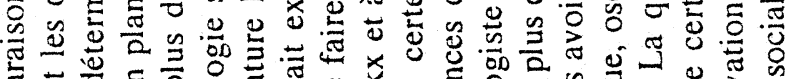

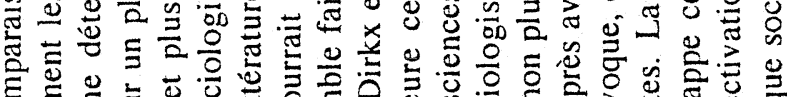

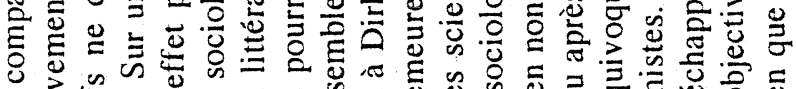

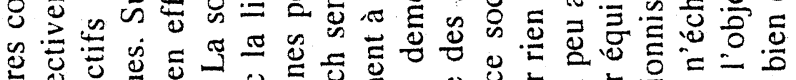

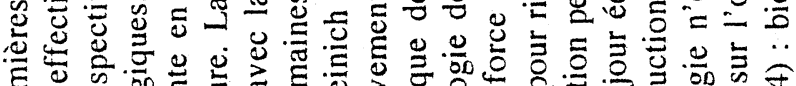

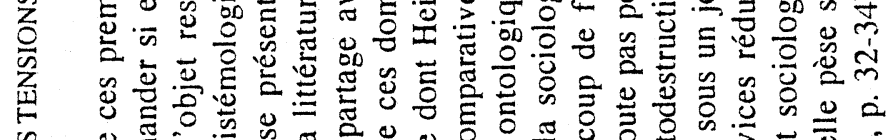

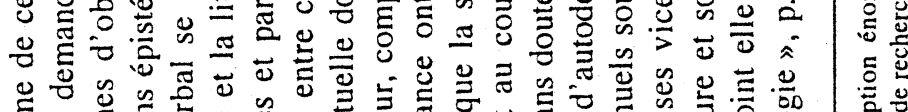

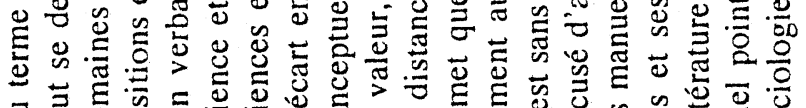

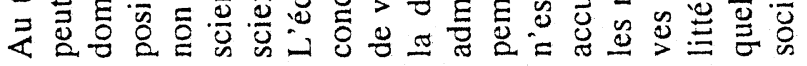

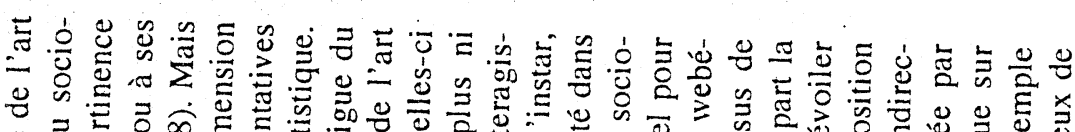

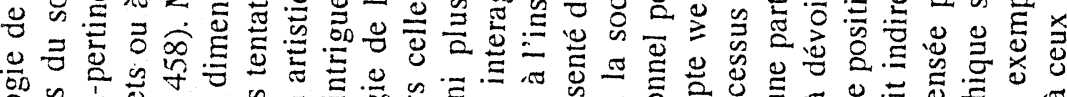

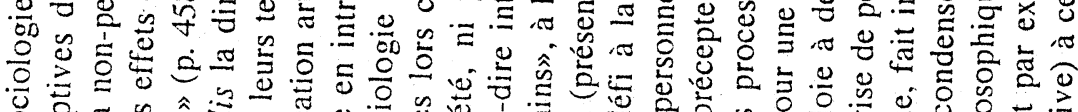

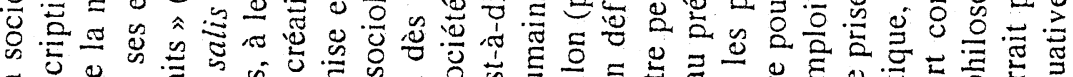

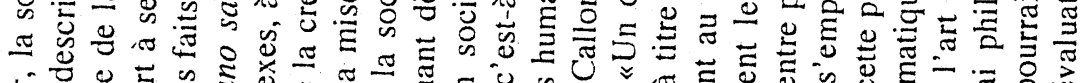

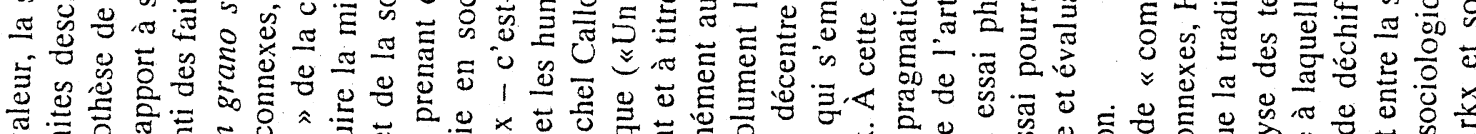

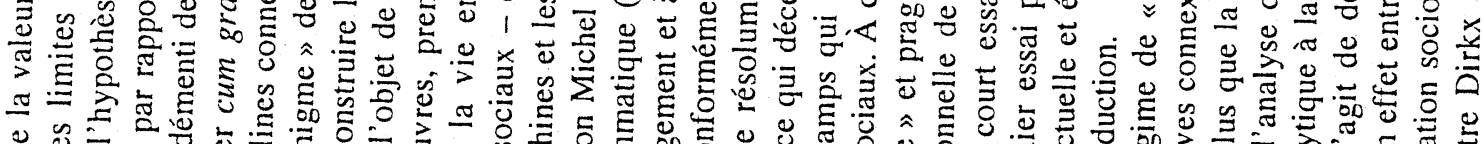

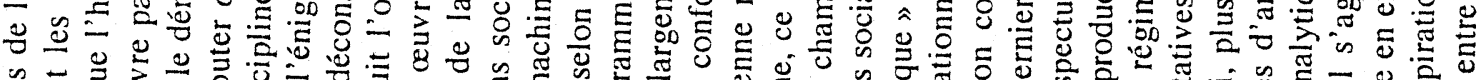

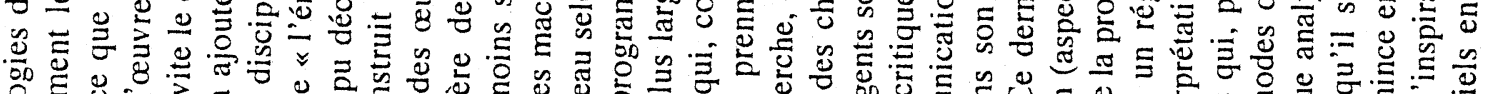

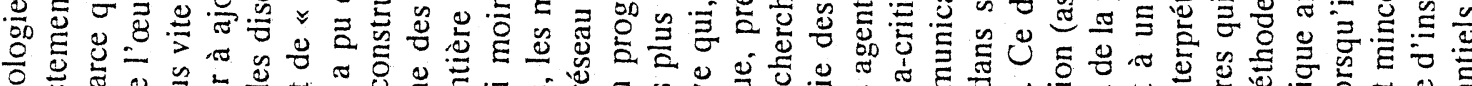

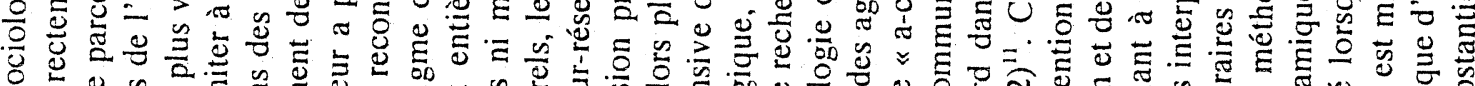

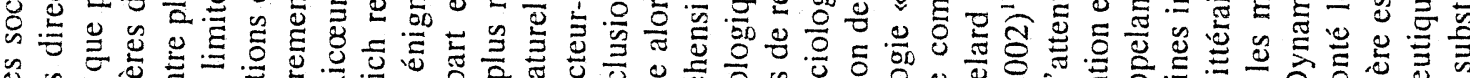

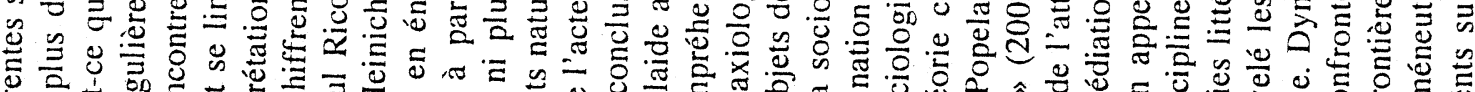

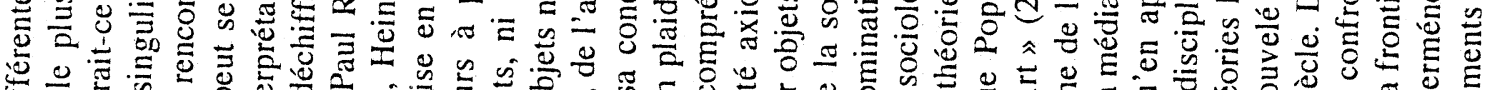

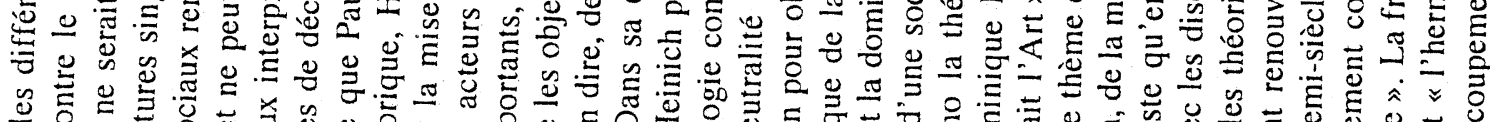

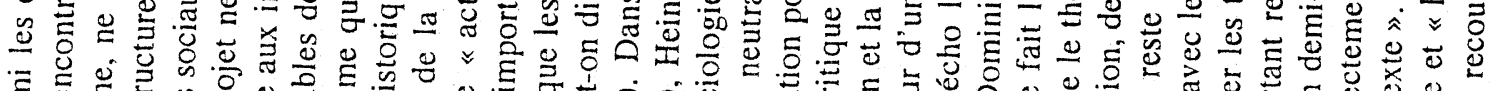

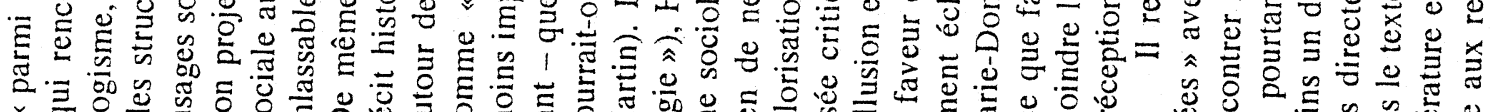

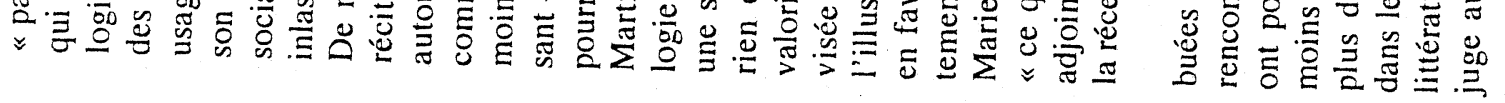




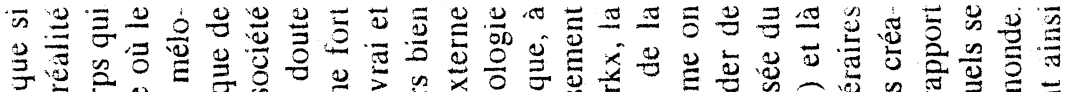

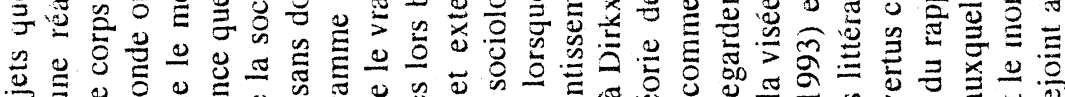

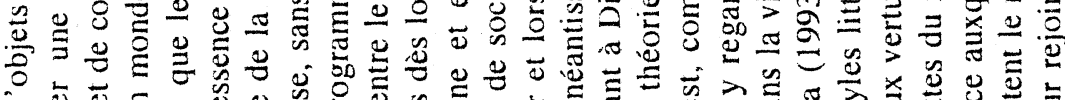

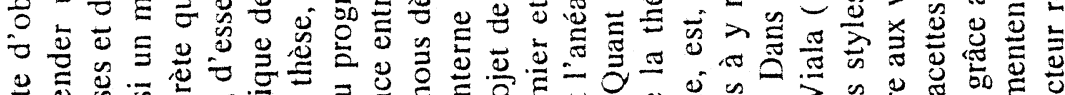

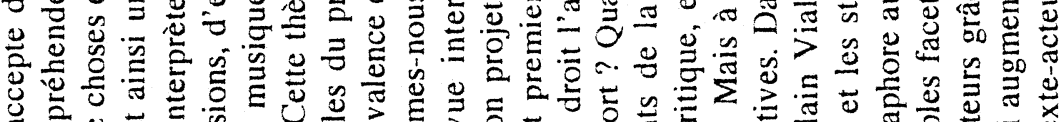

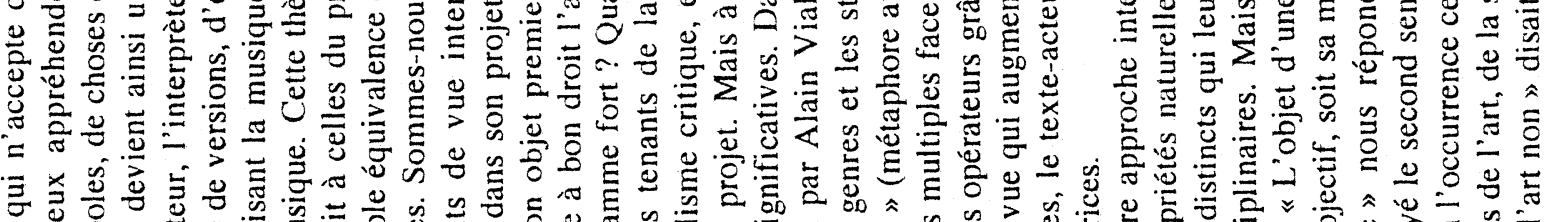

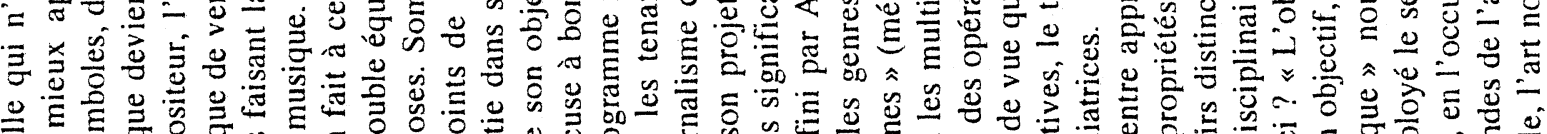

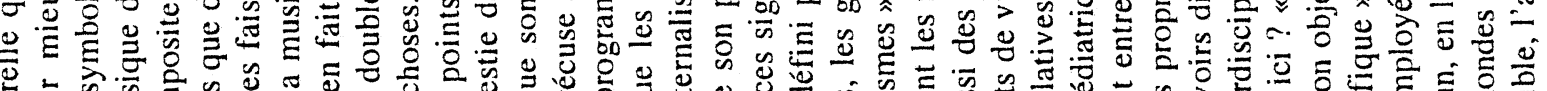

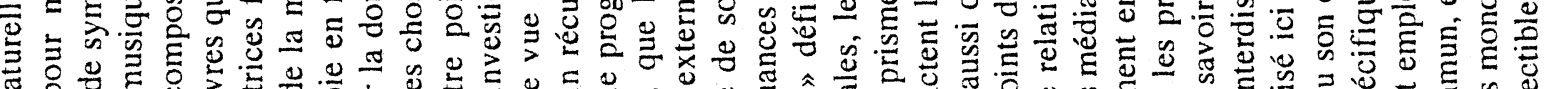

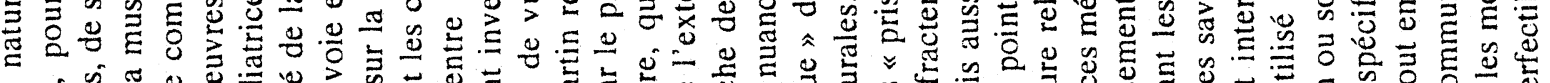

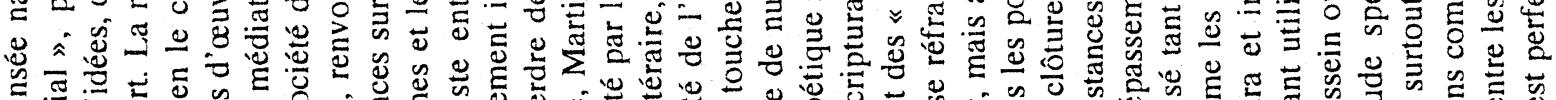

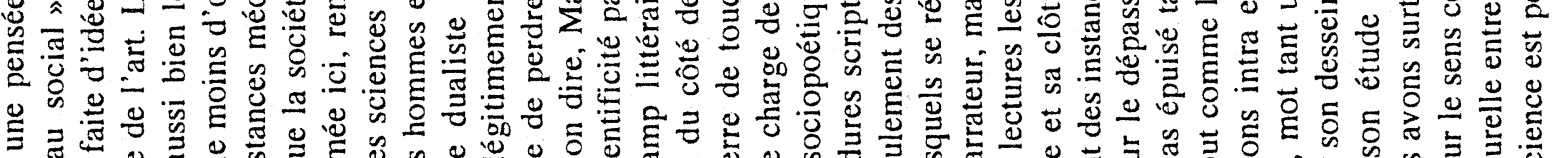

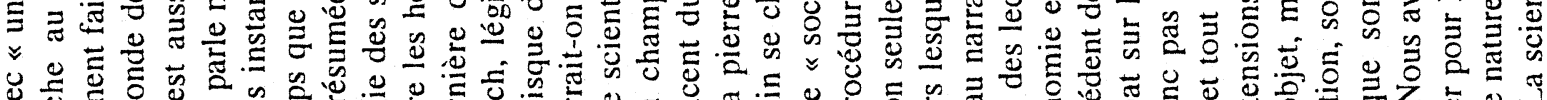

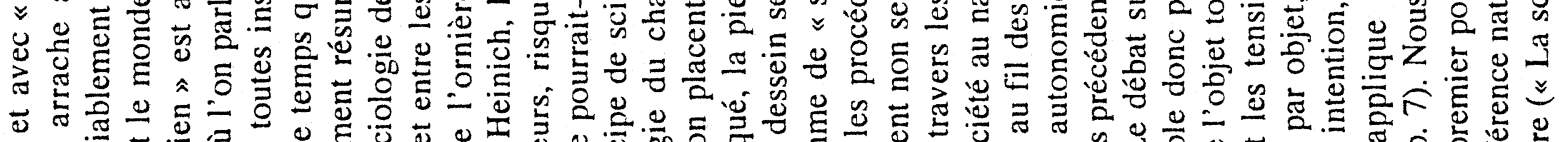

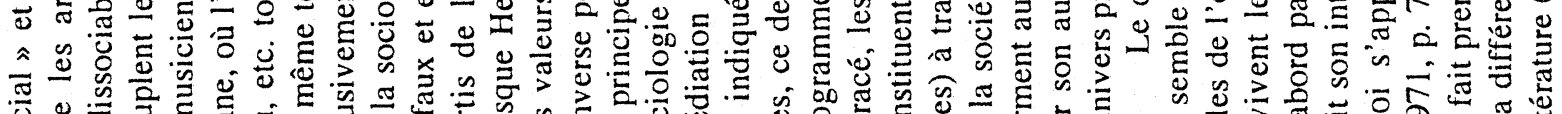

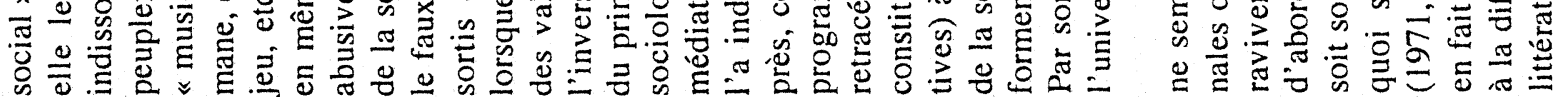

ge日

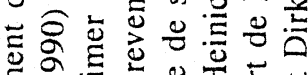

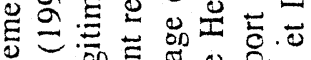

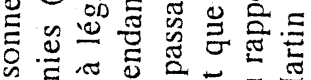

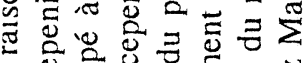
o 5.

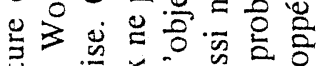

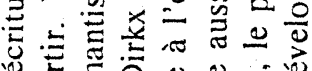

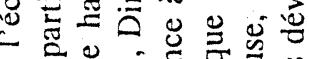

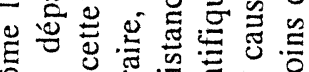

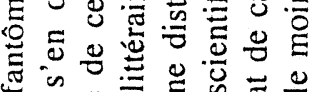

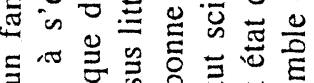

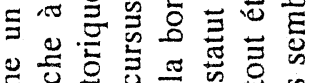

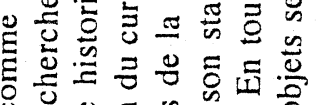

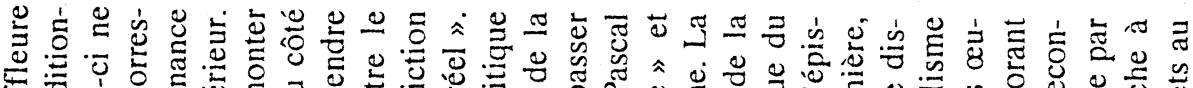

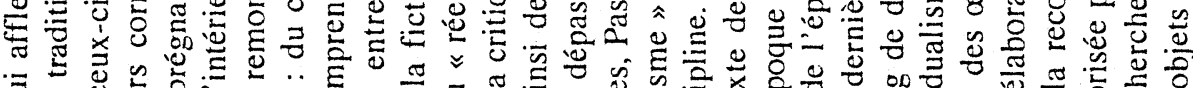

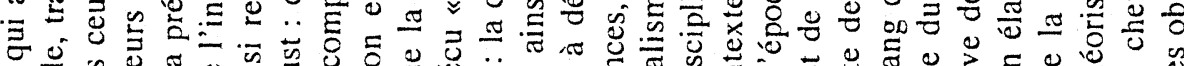

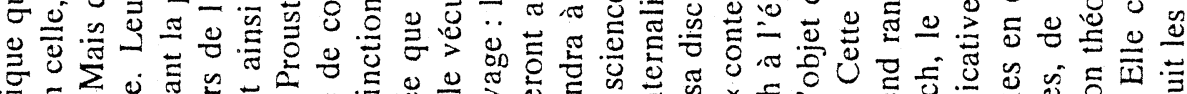

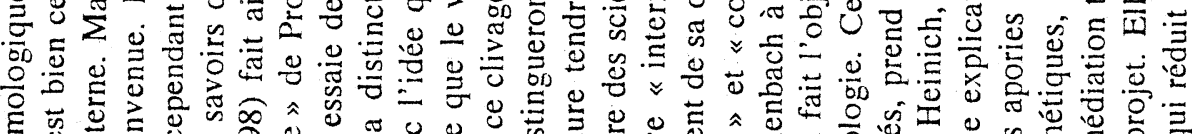

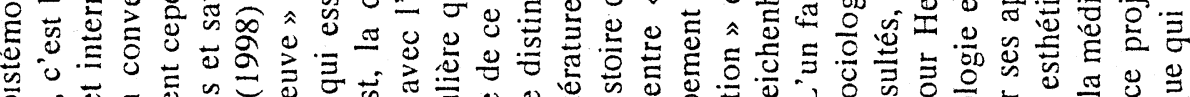

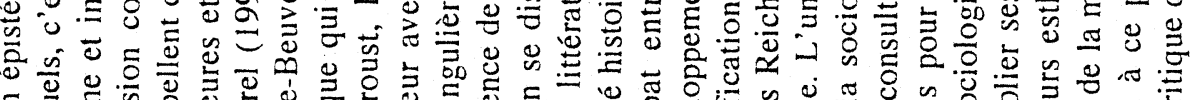

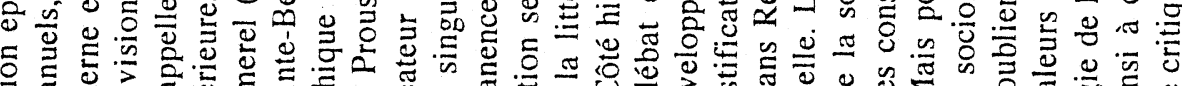

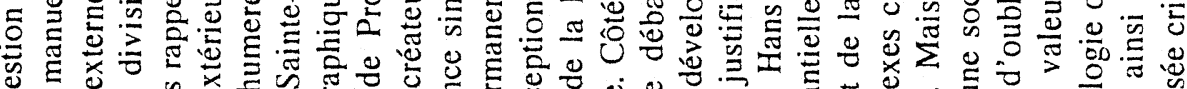
可地 等.

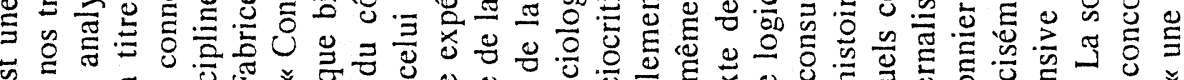
5 s.

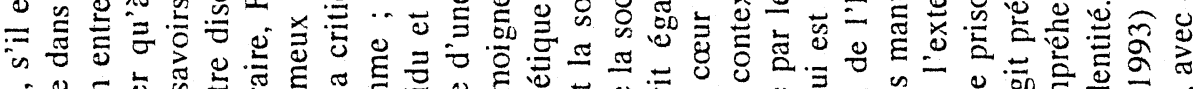

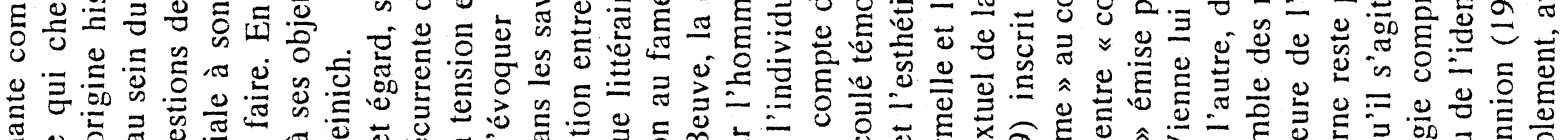

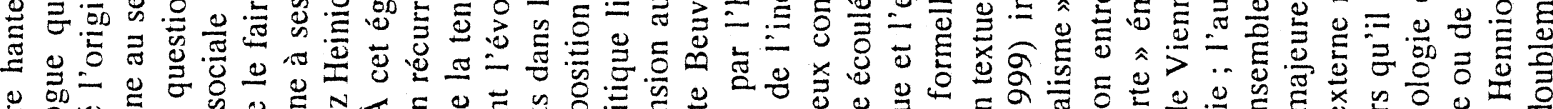

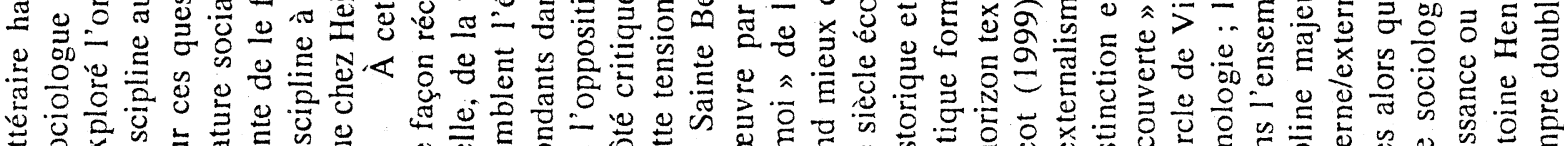

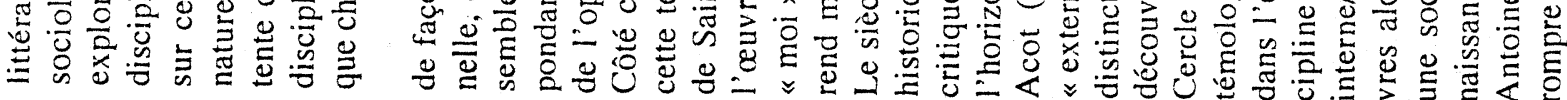




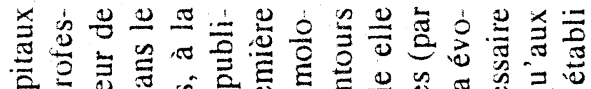

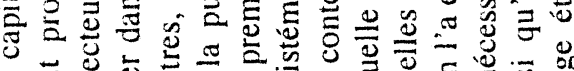

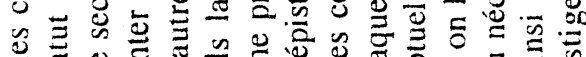

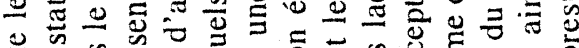

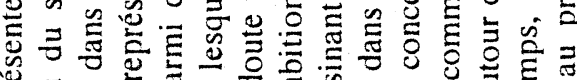

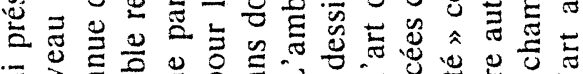

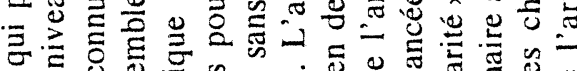

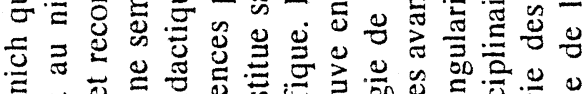

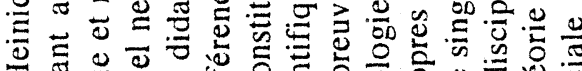

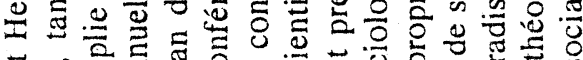

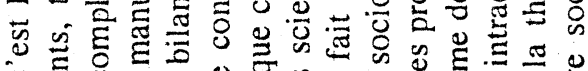
U

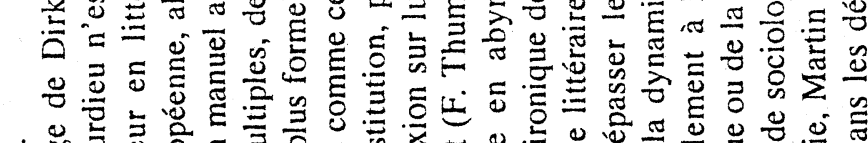

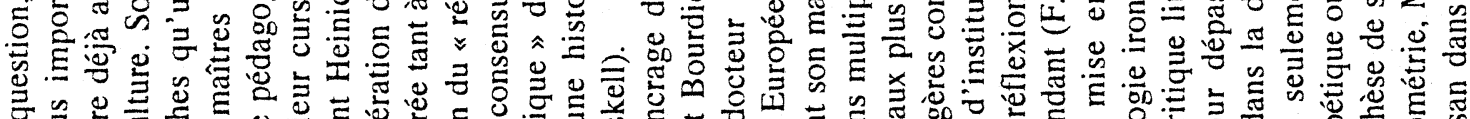

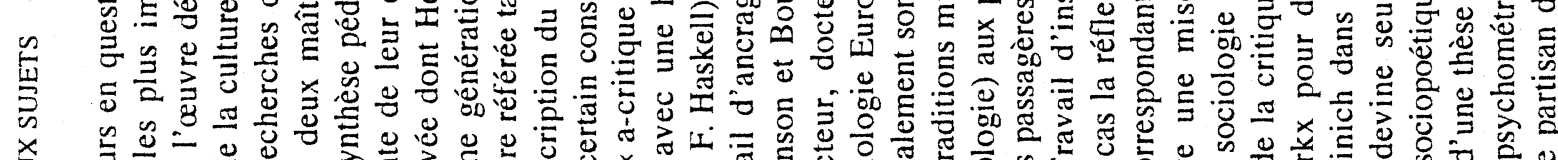

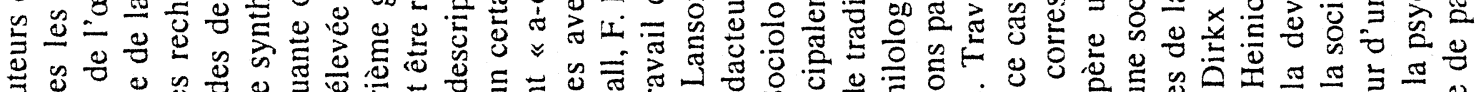

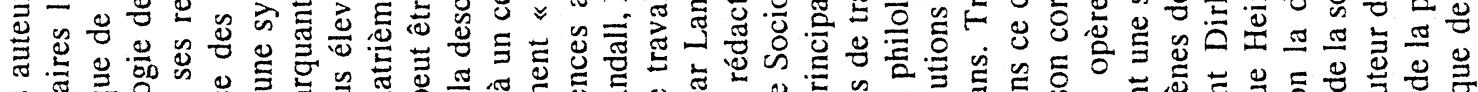

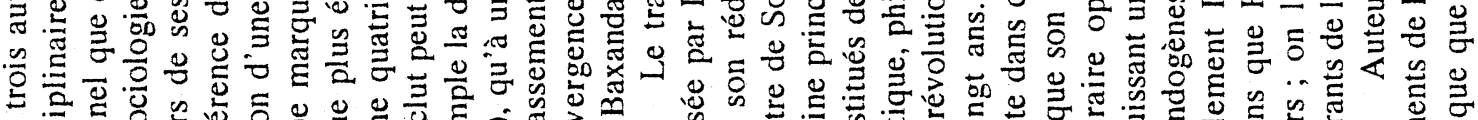

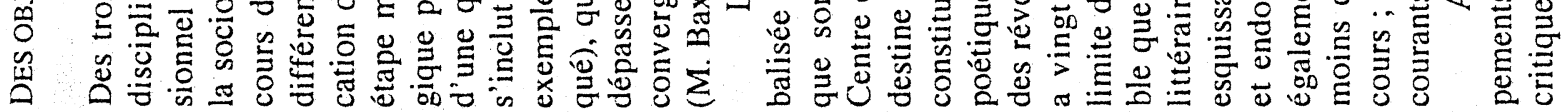

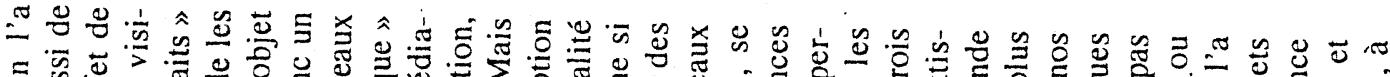

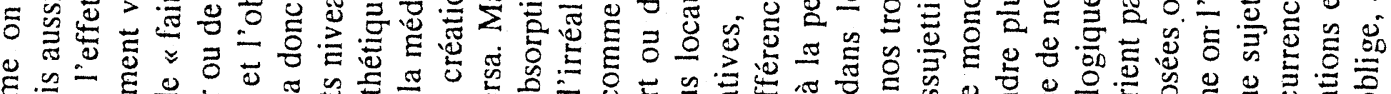

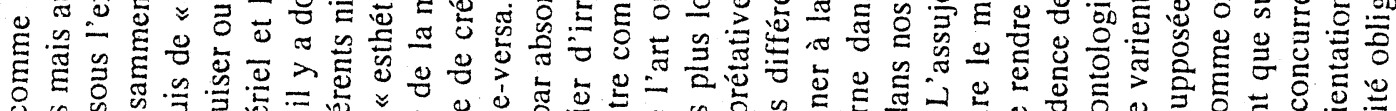

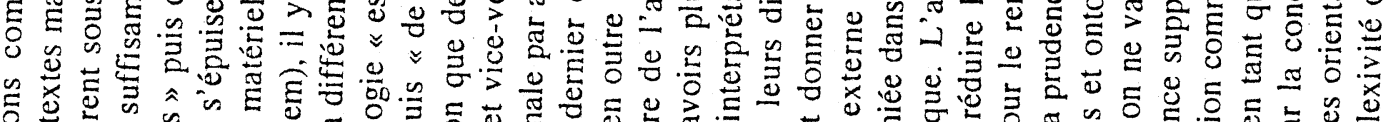

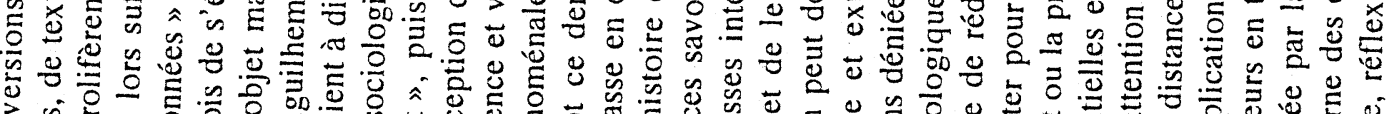

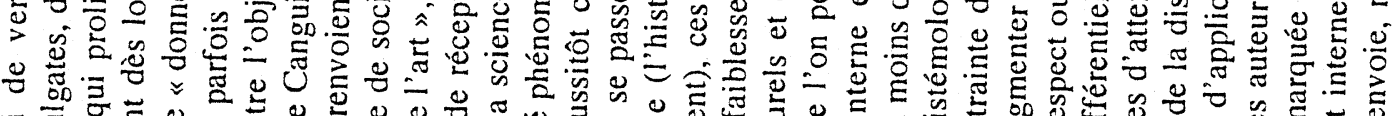

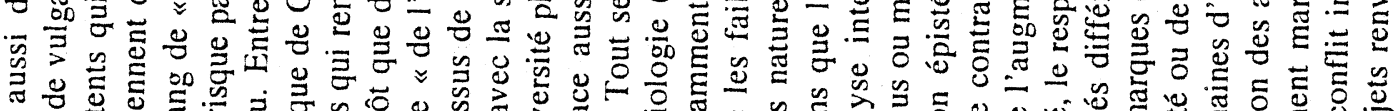

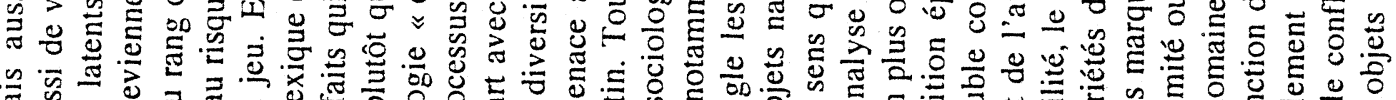

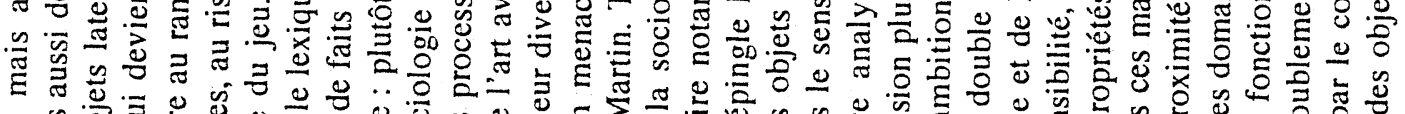

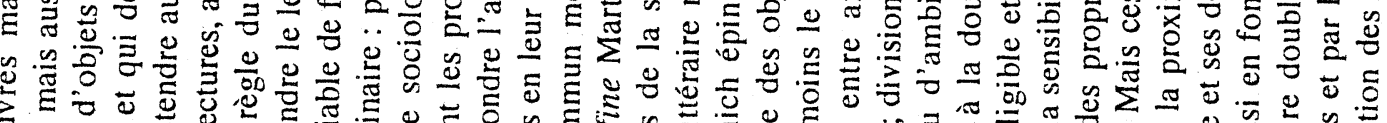

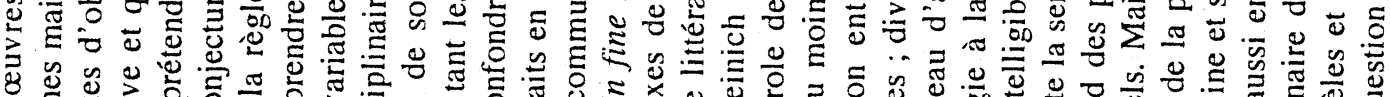

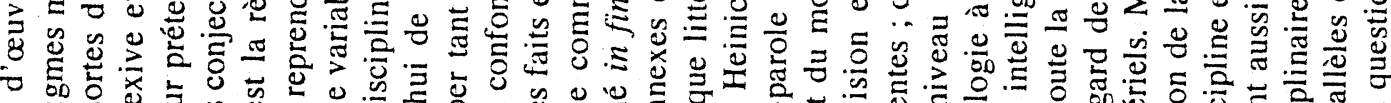

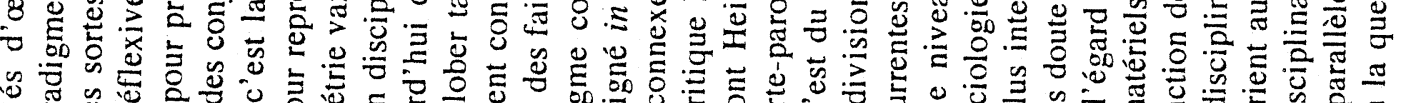

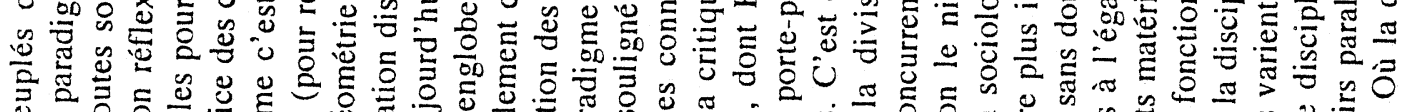

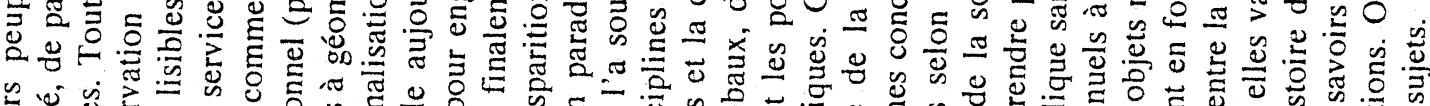

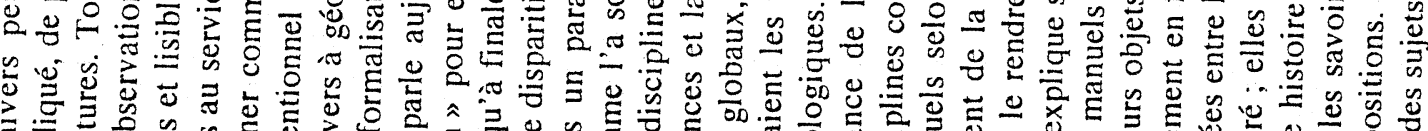

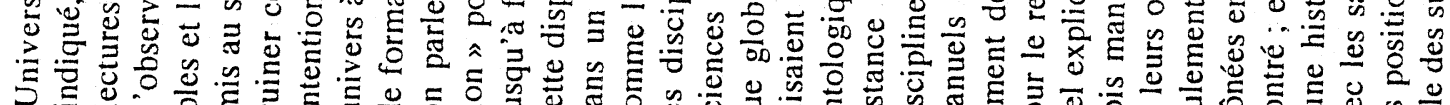

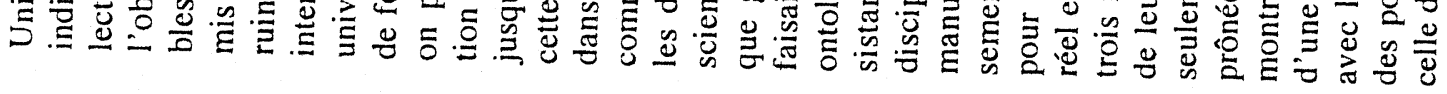




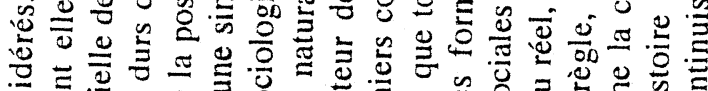

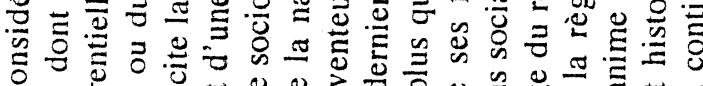

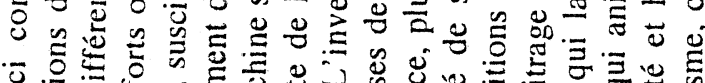

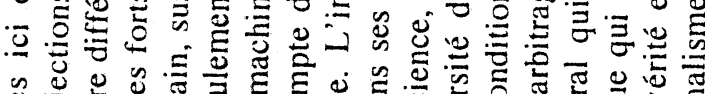

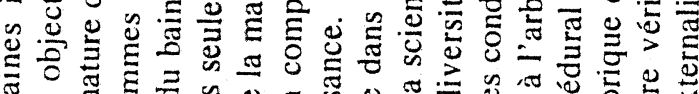
$\begin{array}{lll} & \\ 0\end{array}$

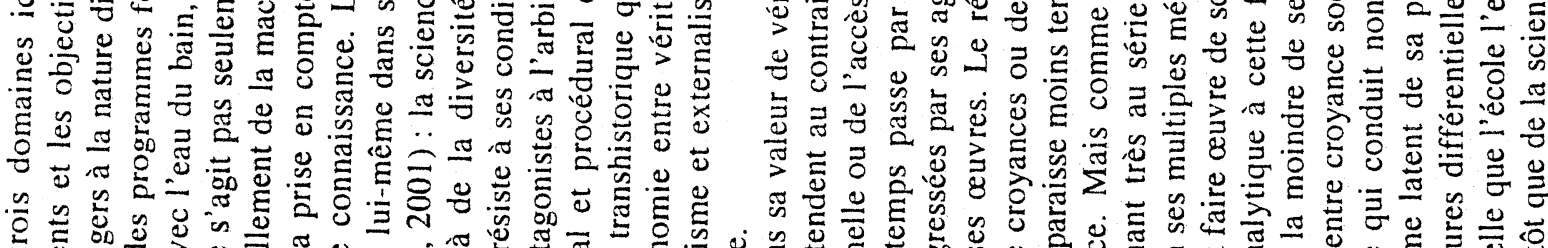

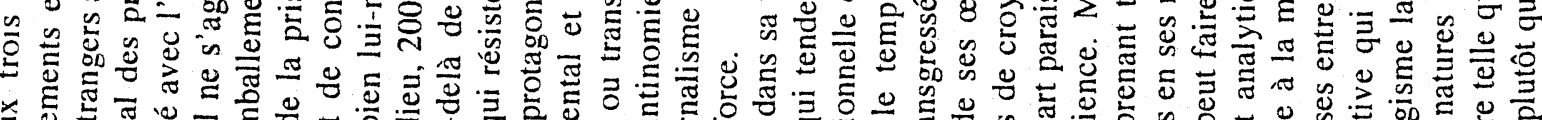

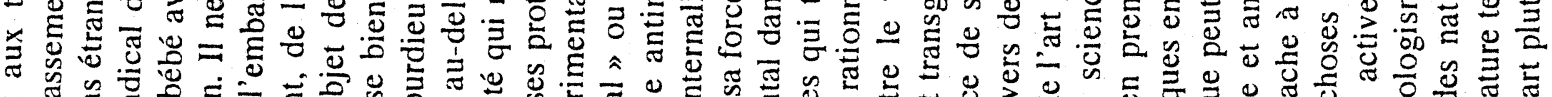

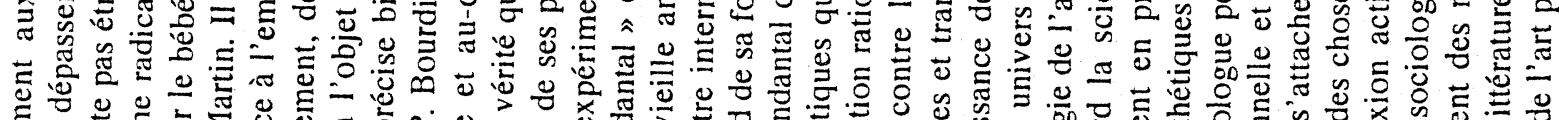

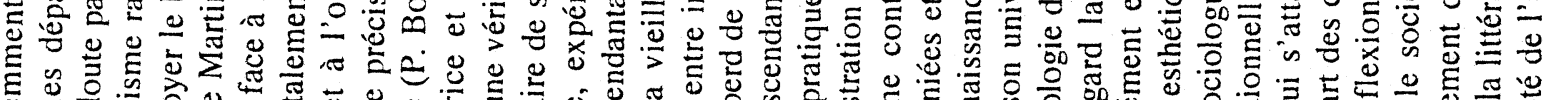

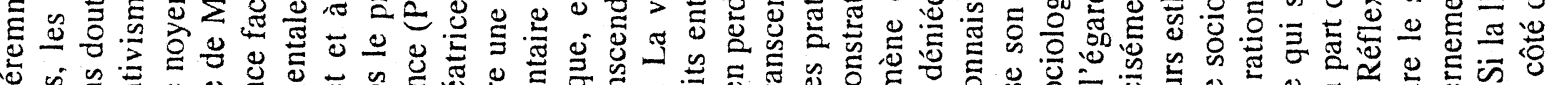

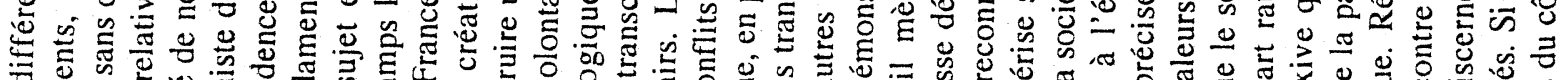

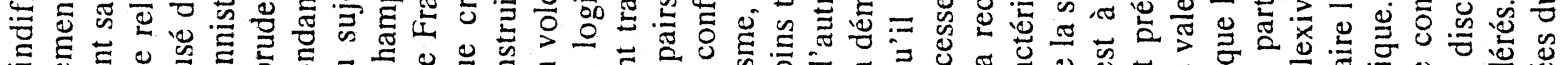

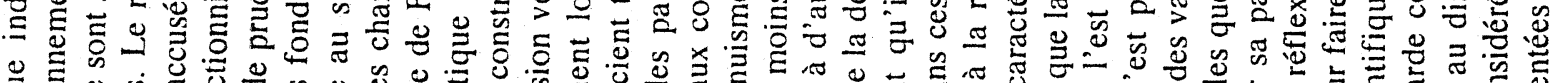

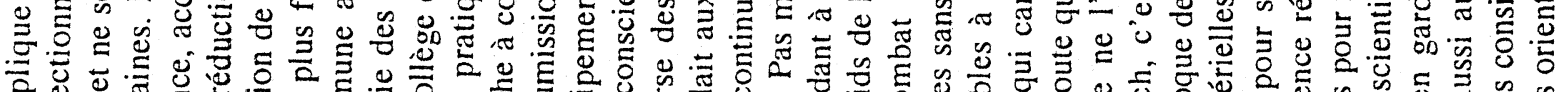

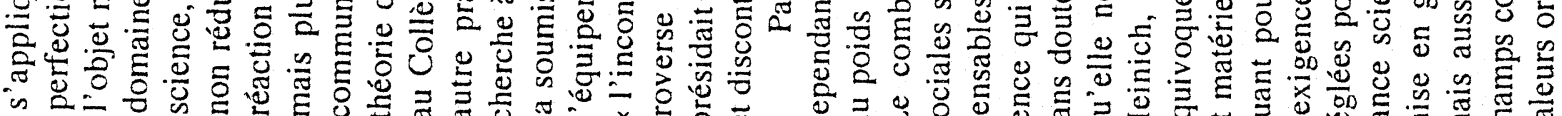

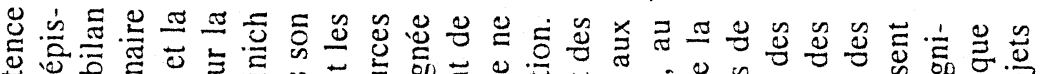

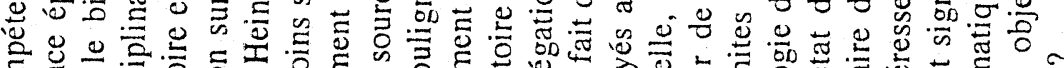

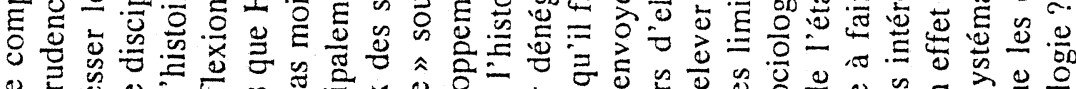

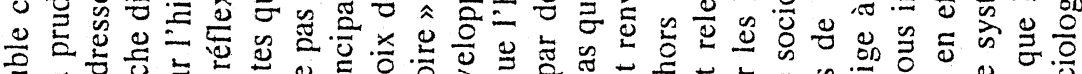

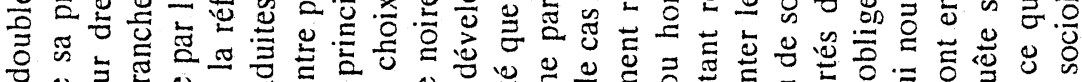

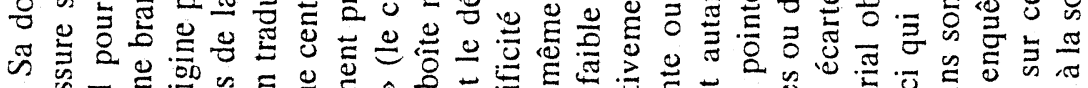

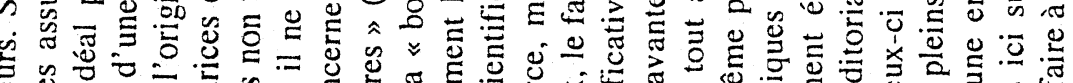

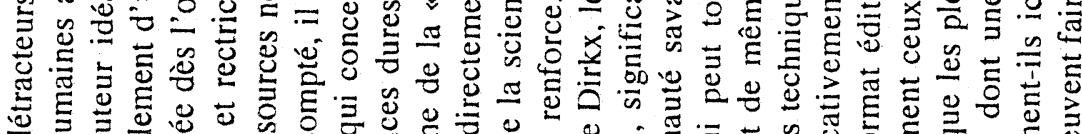

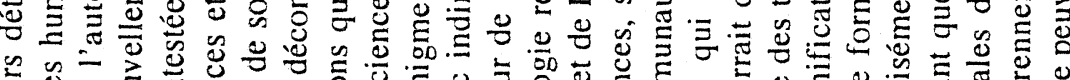

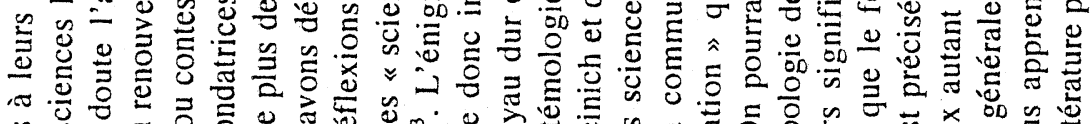

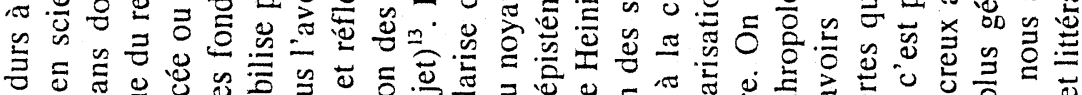

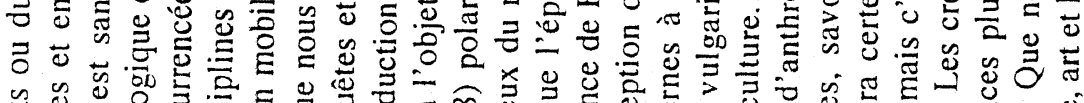

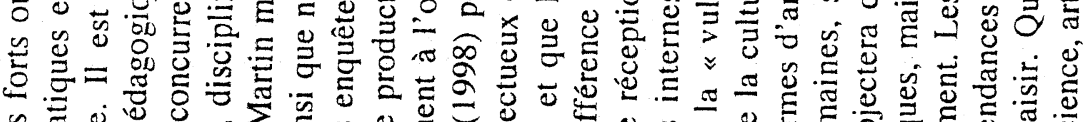

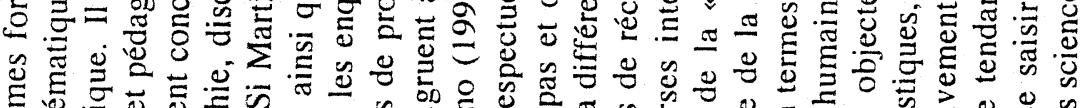

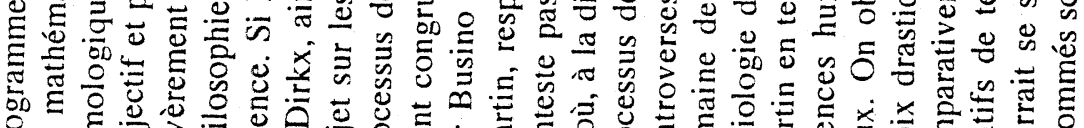

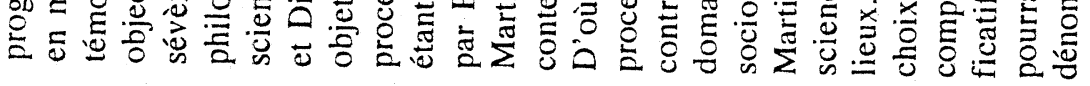




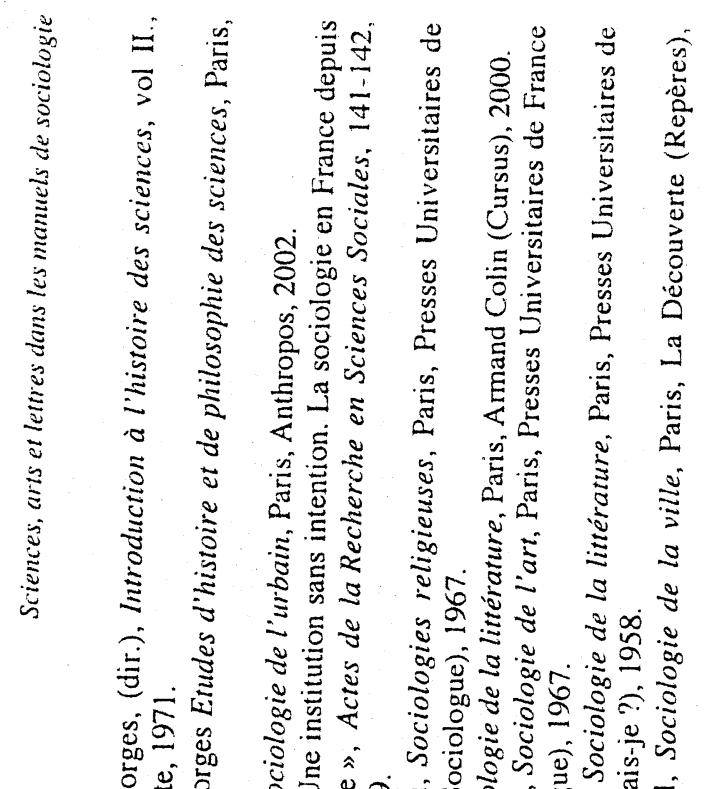

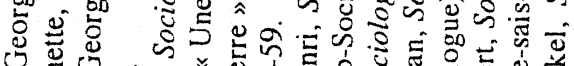

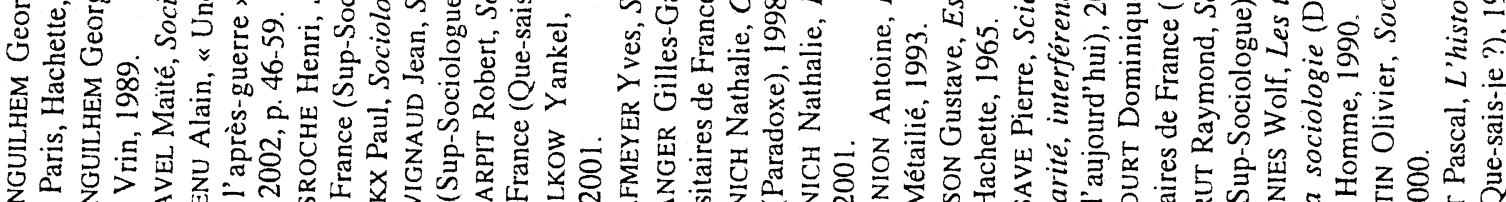

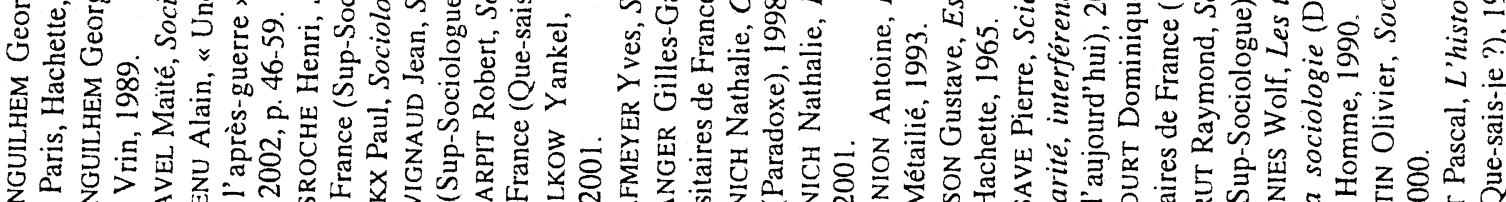

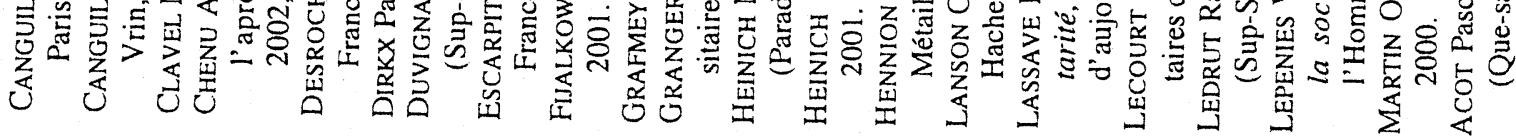

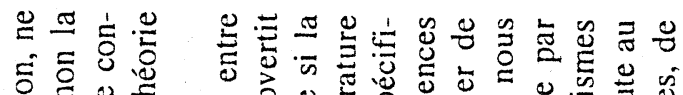

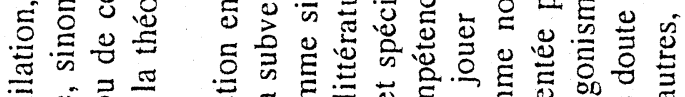

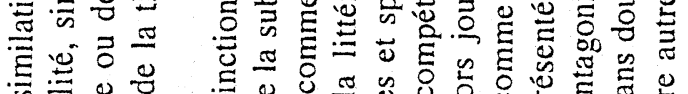

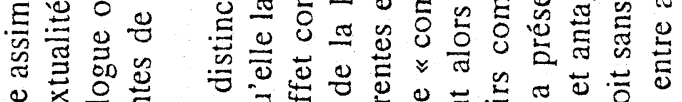

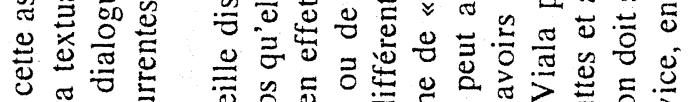

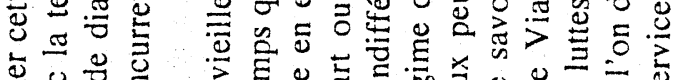

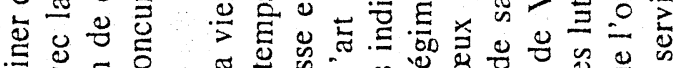

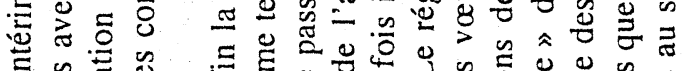

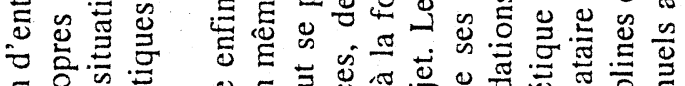

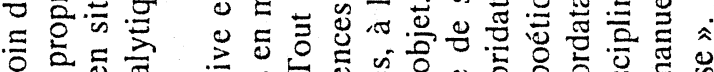

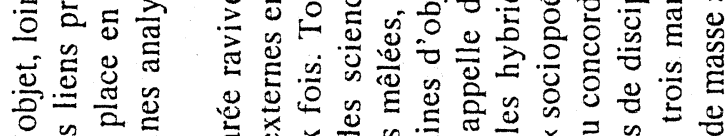

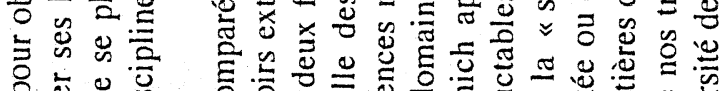

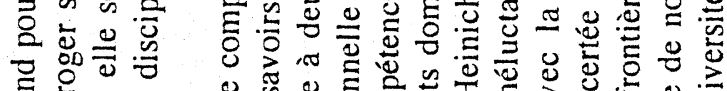

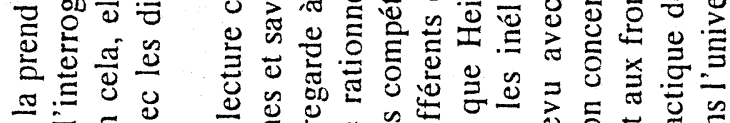

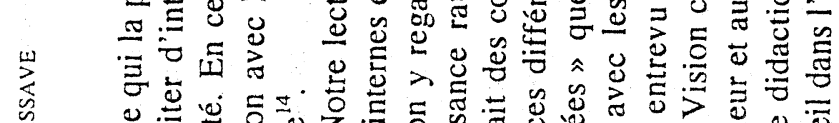

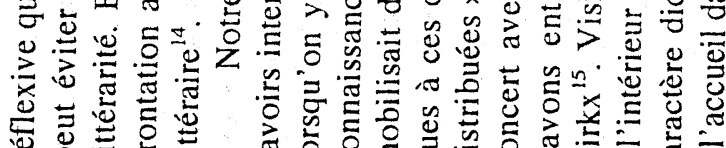

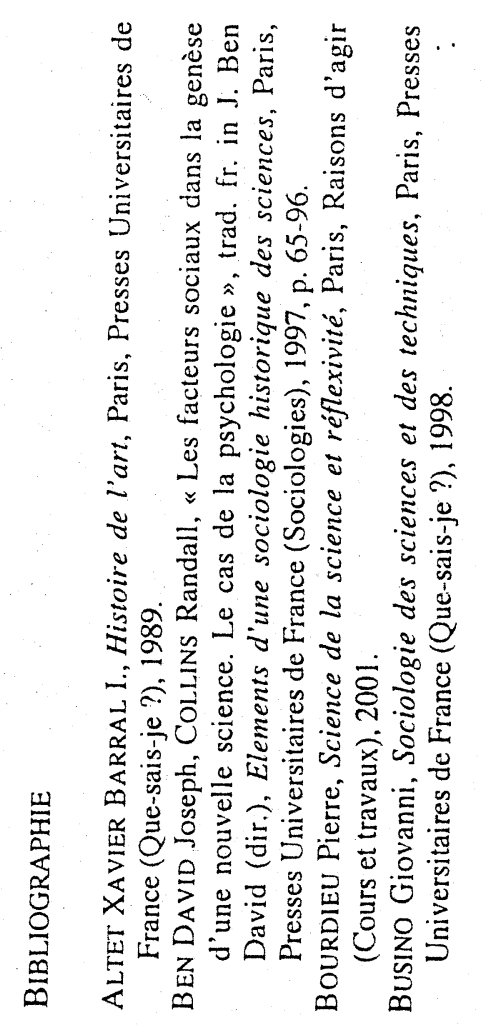




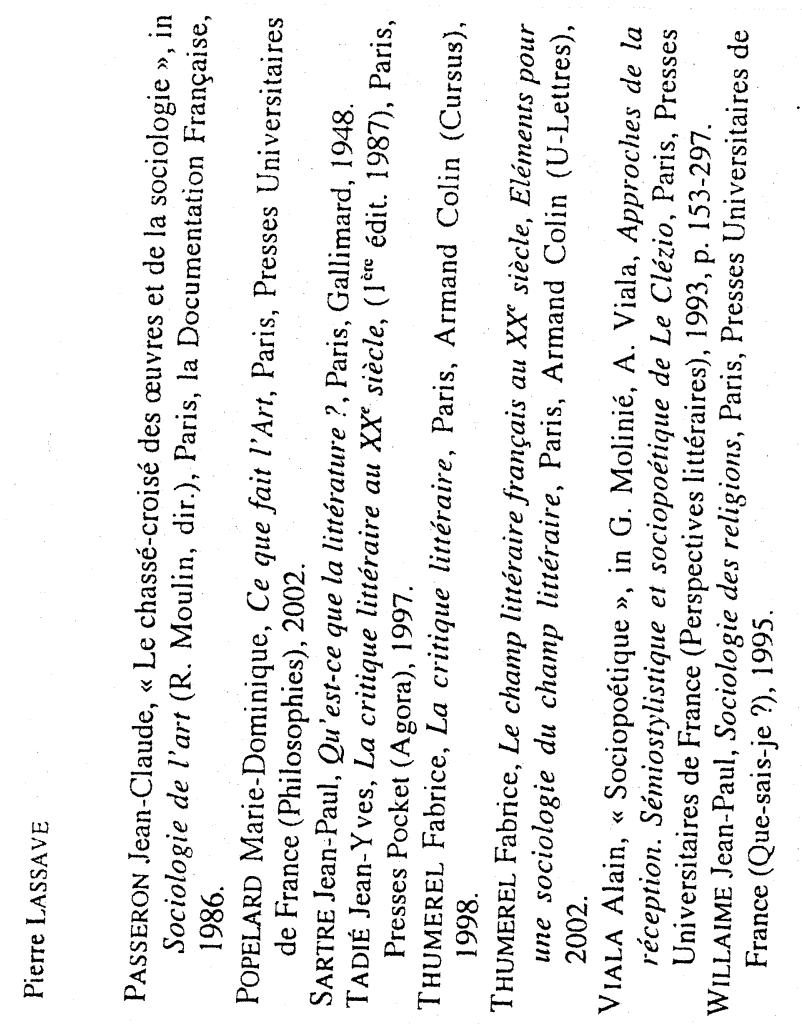

